\title{
The Ishraq Program for out-of-school girls: From pilot to scale-up [Arabic]
}

Mona Selim

Nahla G. Abdel-Tawab

Population Council

Khaled El Sayed

Population Council

Asmaa Elbadawy

Population Council

Heba El Kalaawy

Population Council

Follow this and additional works at: https://knowledgecommons.popcouncil.org/departments_sbsr-pgy

Part of the Demography, Population, and Ecology Commons, Family, Life Course, and Society

Commons, and the International Public Health Commons

How does access to this work benefit you? Let us know!

\section{Recommended Citation}

Selim, Mona, Nahla G. Abdel-Tawab, Khaled El Sayed, Asmaa Elbadawy, and Heba El Kalaawy. 2013. "The Ishraq Program for out-of-school girls: From pilot to scale-up," Final report [Arabic]. Cairo: Population Council. 
التقــريــر النهــائـي

$$
\begin{aligned}
& \text { برنامـج إشـراق للفتيات المتســـــات مـن }
\end{aligned}
$$

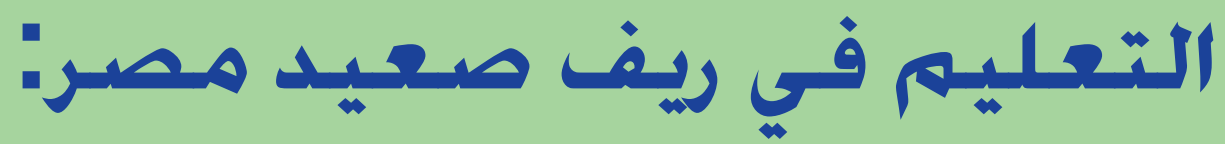

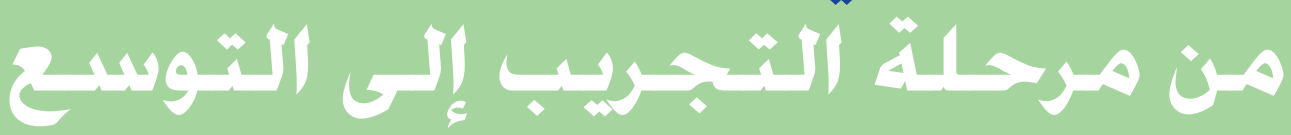

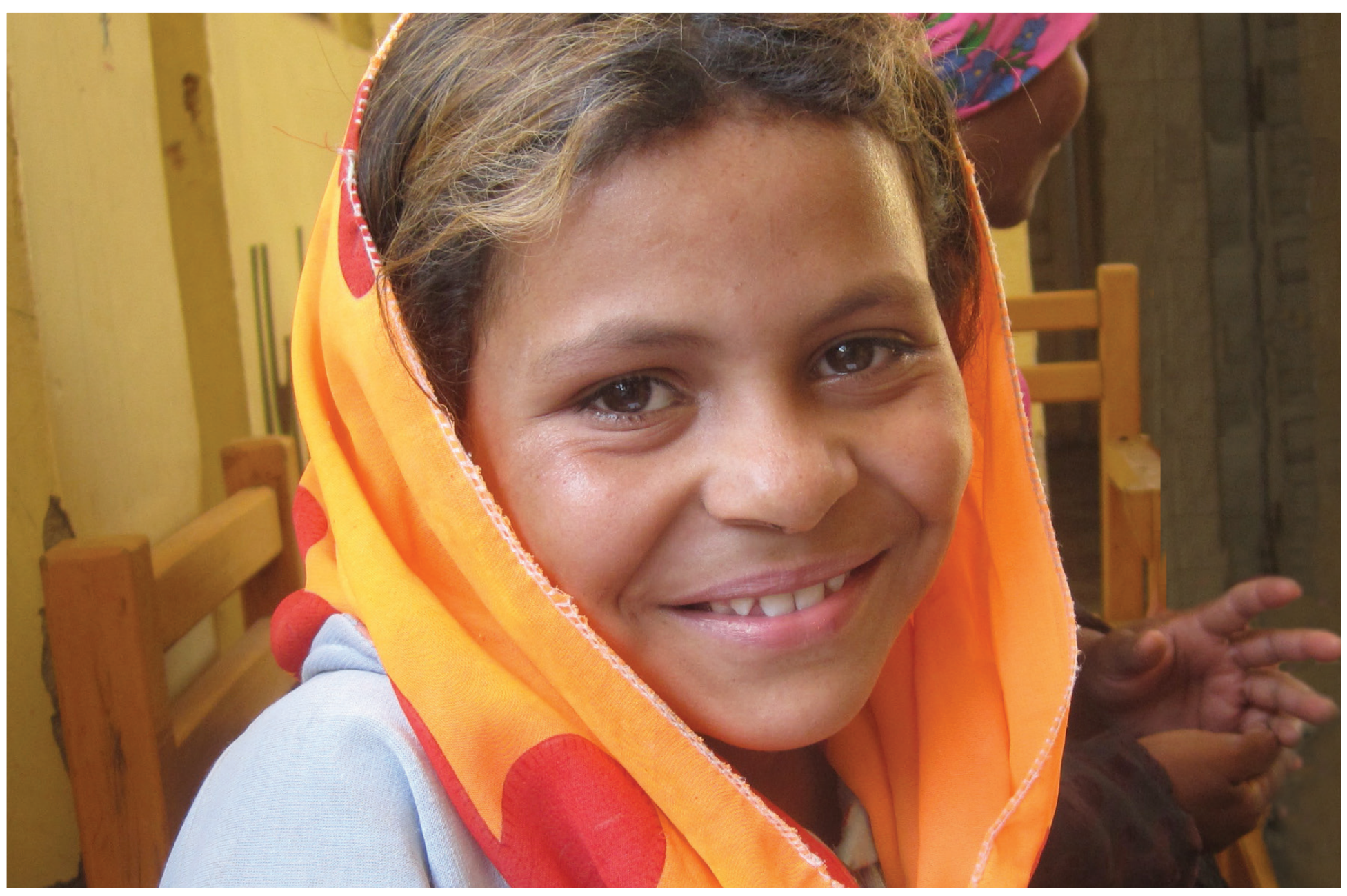

منس سـليم

نهلة عبد التواب

خالـد السـيد

أسسماء البدوي

هبـ القلعـاوي البدوي

(f Population Council 



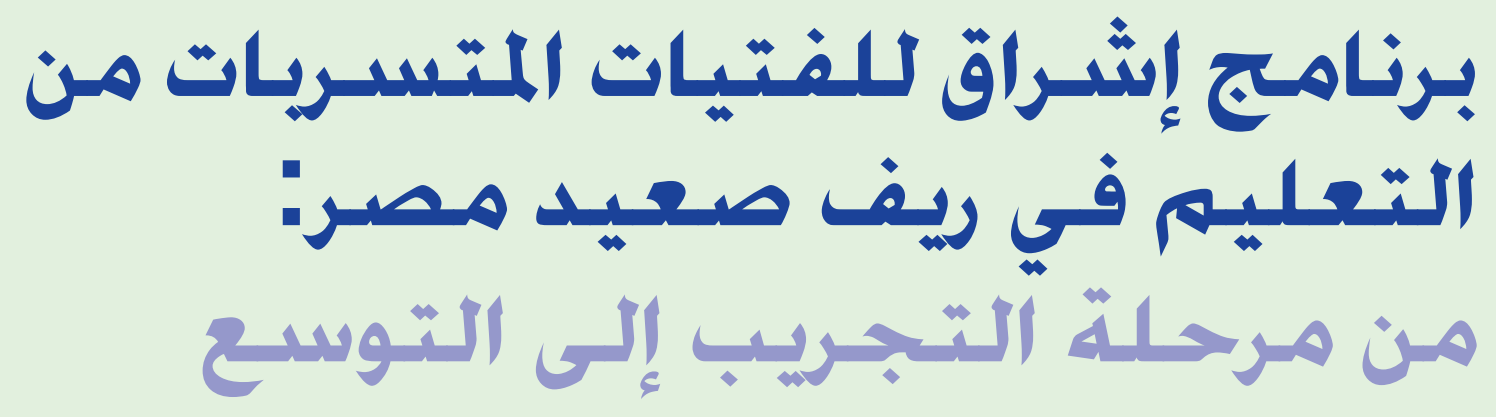

منس سـليهم

نهلة عبد التواب

خالد السـيد السيد

أسـمـاء البدوي البدي

هبــ القـلعـاوي البدوي

(f) Population Council 


\section{(2) Population Council}

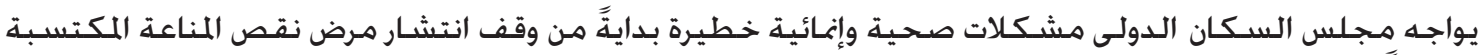

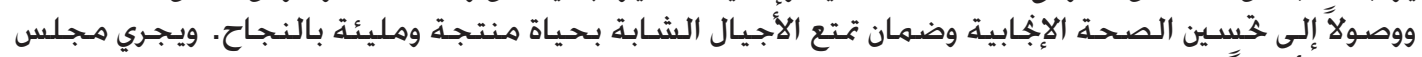

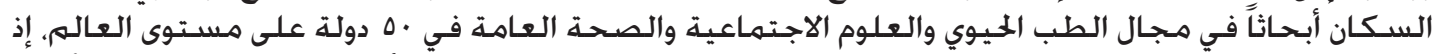

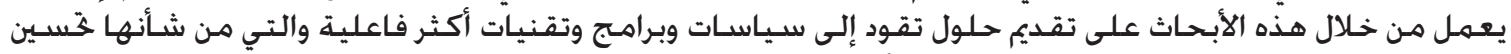

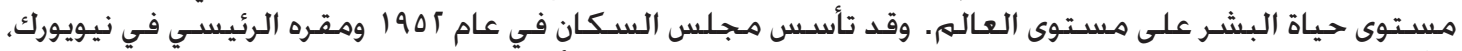
والجملس منظمة خياة فير حكومية وغير هادفة للربح يتولى إدارتها مجلس أسلس أمناء دولي.

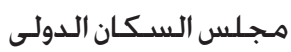
One Dag Hammarskjold Plaza New York, NY 10017

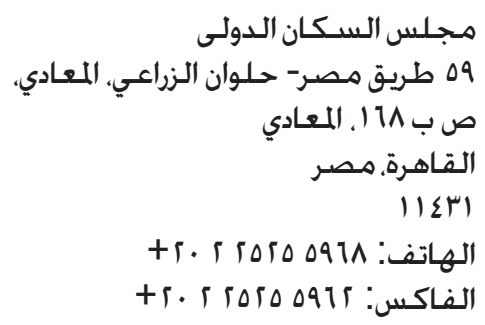

www.popcouncil.org

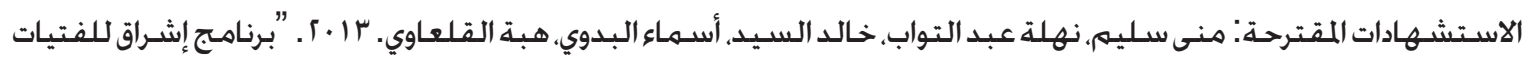

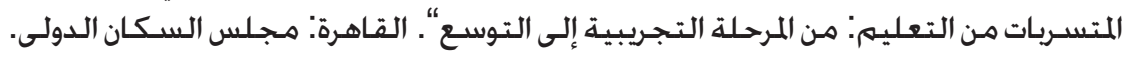




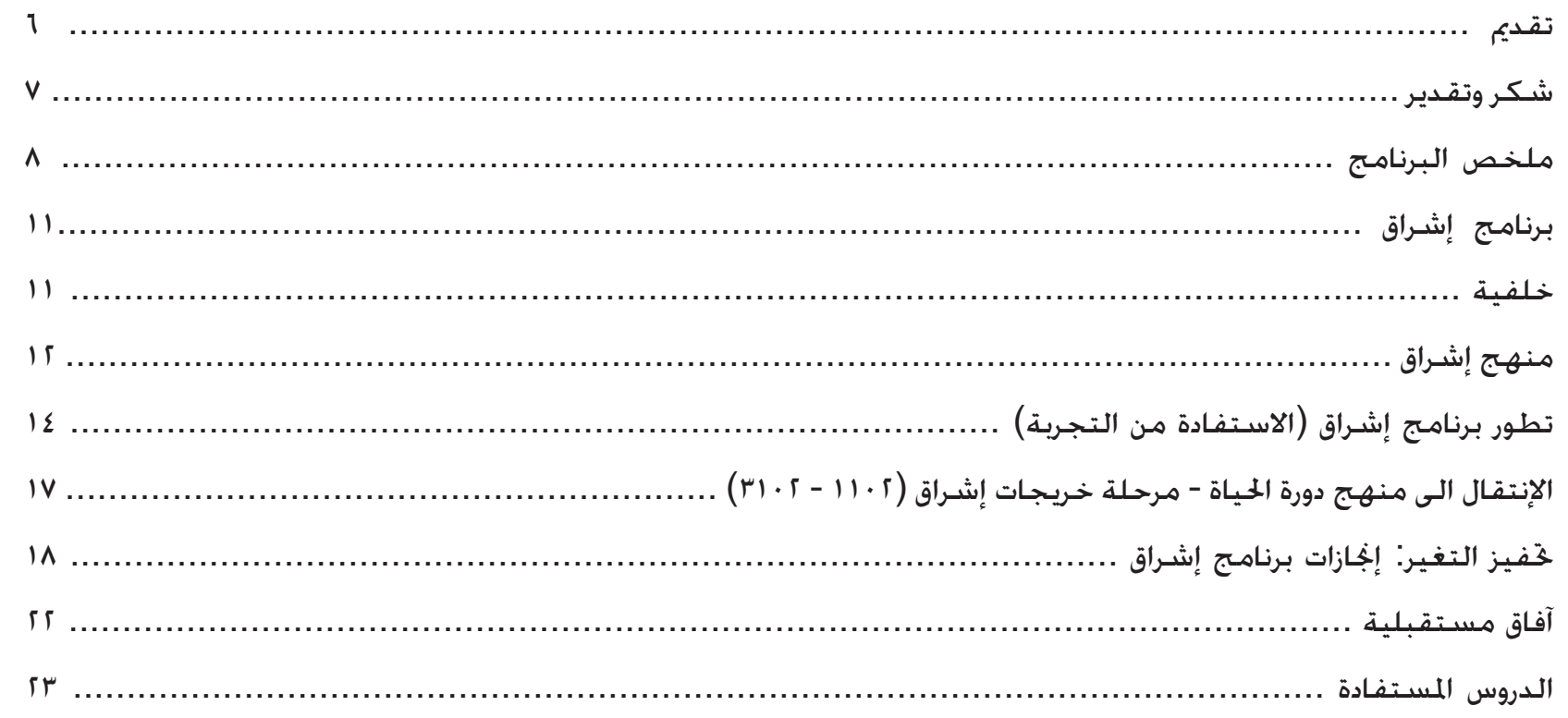


ويـود مجـلس السـكان الدولى التعبير عن عميق امتنانه للحكـومـة الهولنديـة على دعمهها طويل المدى لبرنامـج إشـراق.

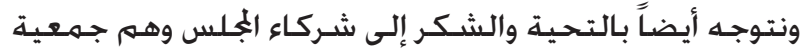

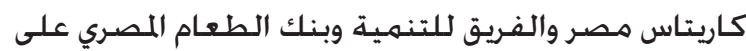

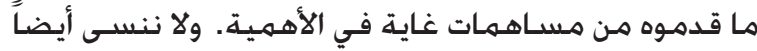

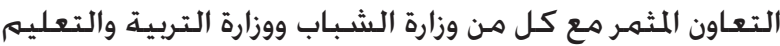

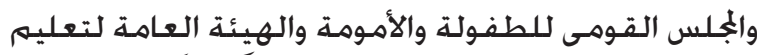

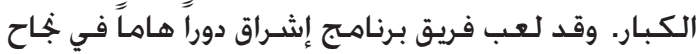

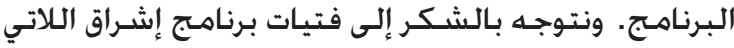

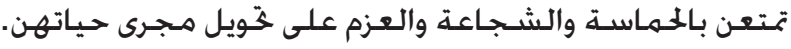
آن كيـه بـلانك

نائب الرئيس ومدير البرنامـج

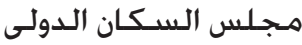

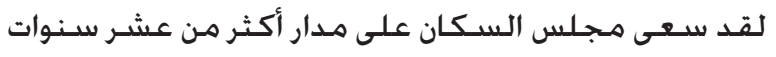

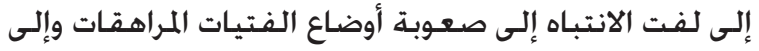

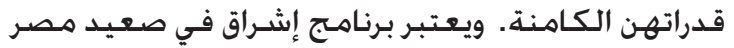

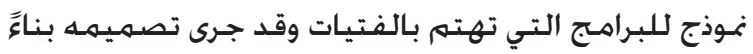

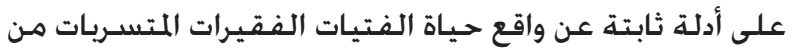

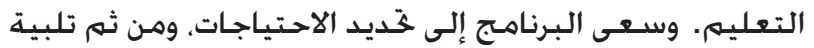

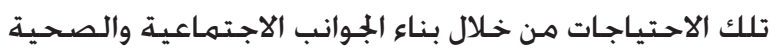

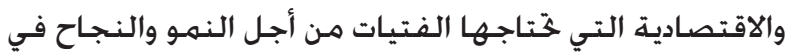

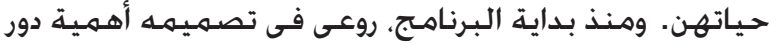

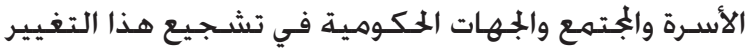
وضـمان اسـتمراريته.

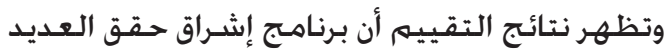

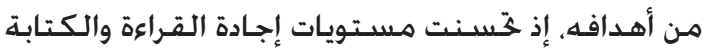

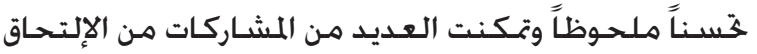

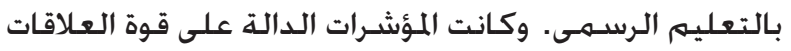

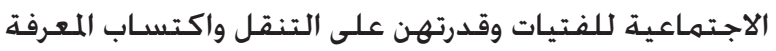

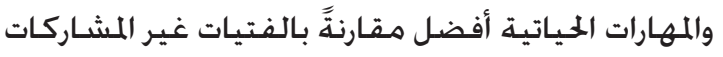

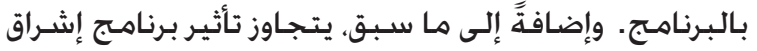

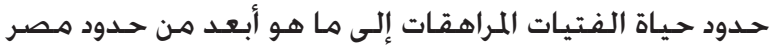

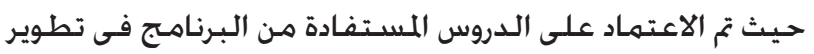

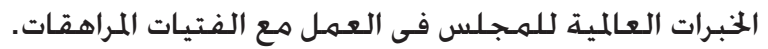

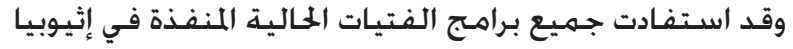

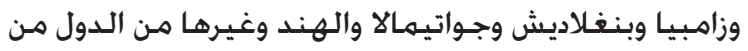

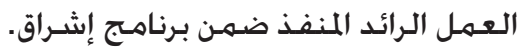


النسـائية لتحسـين الصحـة في محافظة سـوهـاج ومؤسـسـة

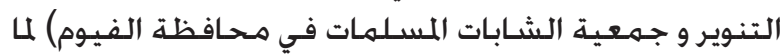

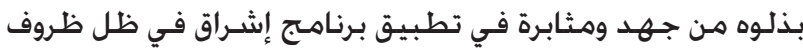

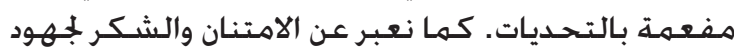

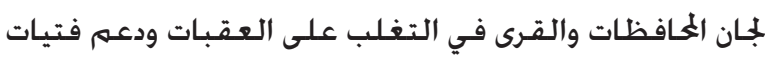
البرنامـج وأسـرهن.

وله يكـن هذا البرنامه ليرى النور لولا حسماس وجهـد فتيات

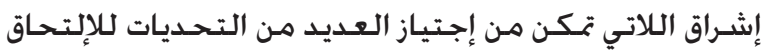

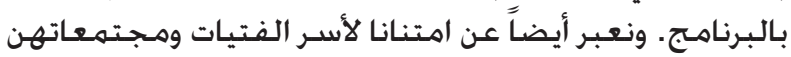

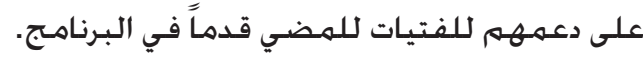

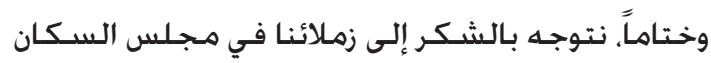

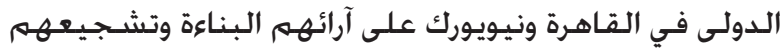
لنا طوال مدة البرنامـج.

الآراء المطروحـة في هـذا التقرير هي آرائنـا الشـخـصية

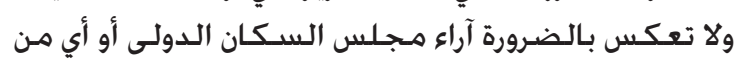
المؤسسـات الشـريكة.
لقـد مـر برنامـج إشـراق بـالعديد مـن المراحل وهي المرحلـة

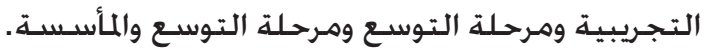

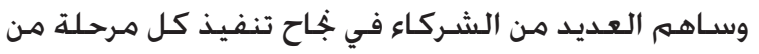

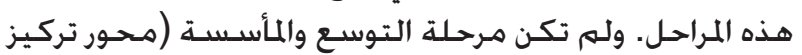

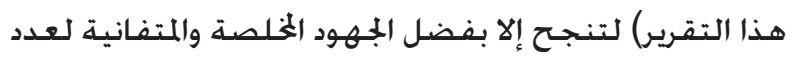

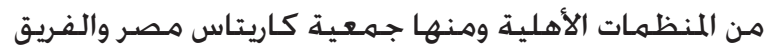
للتنمية وبنك الطعام المــري ومـجـلس السـكان الدولى.

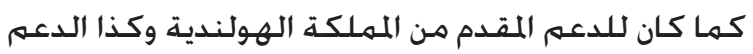

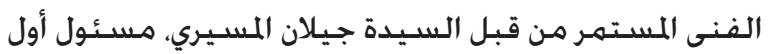

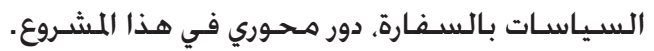

ونود التوجـه بشـــر خـاص إلى شـركاء البرنامـج الحـكوميين

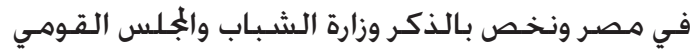

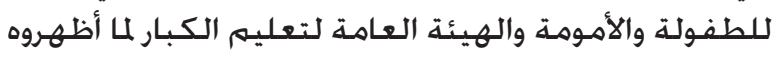
من دعـم للفتيات المتسـريات من التعليهم ورغبتهـهم في اسـتمـرار

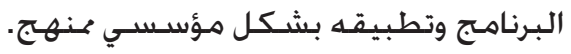

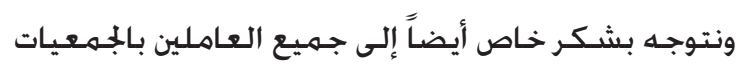

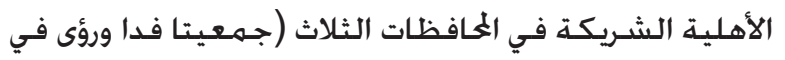

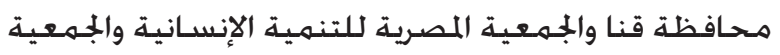

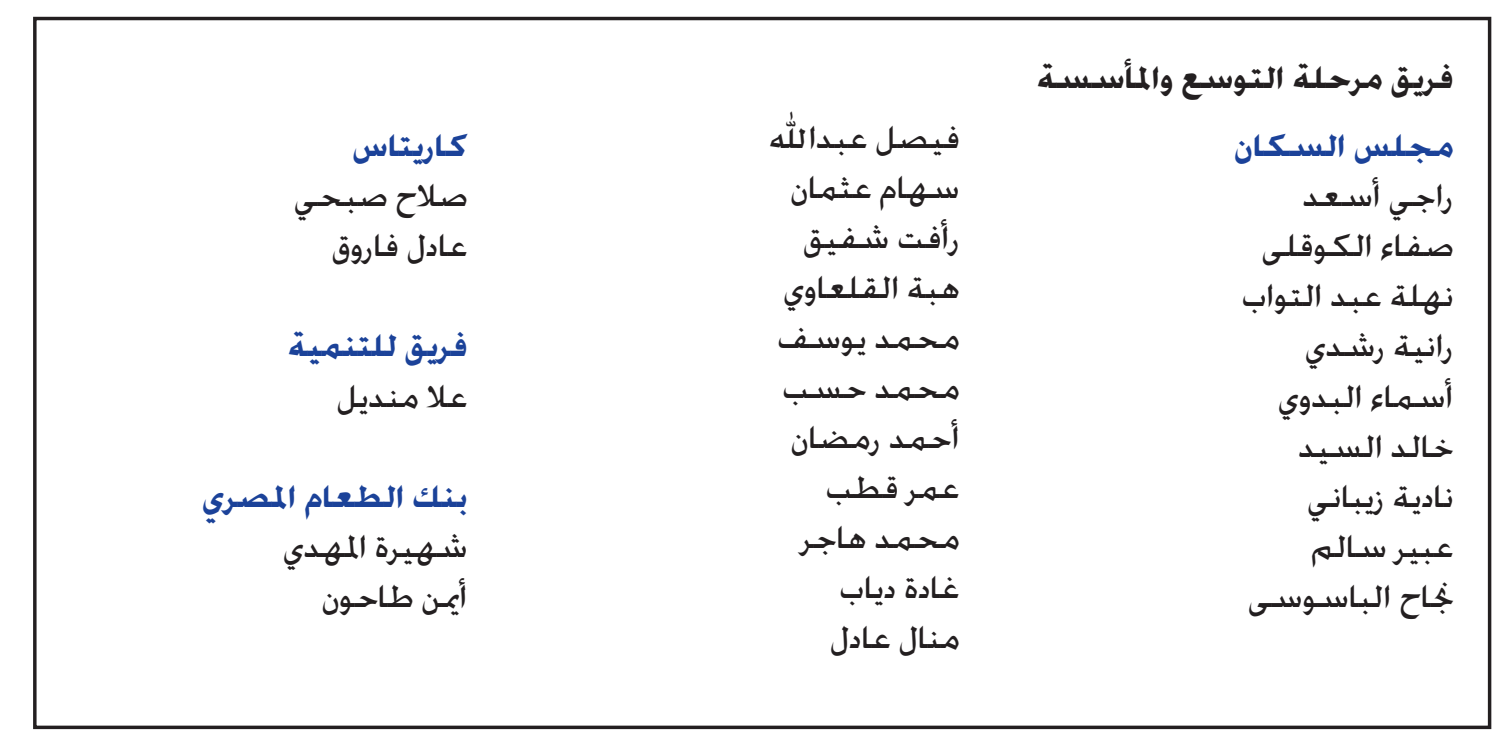




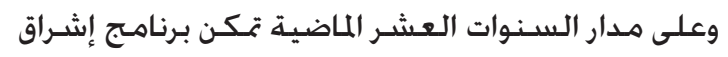

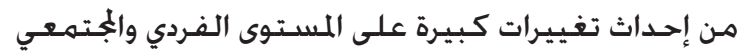

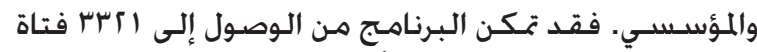

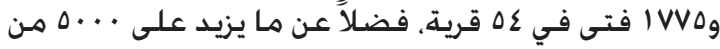

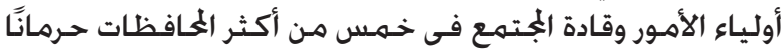

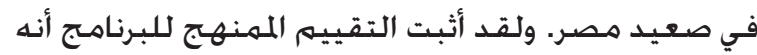

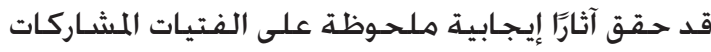

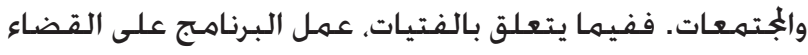

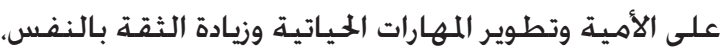

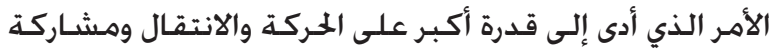

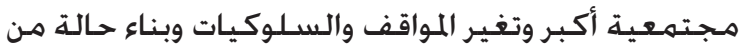

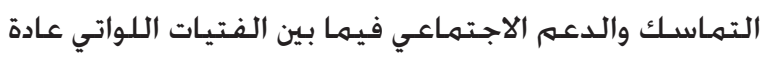

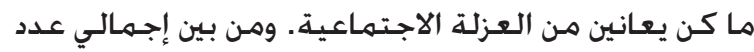

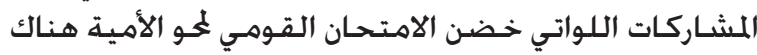

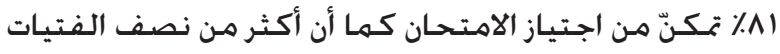

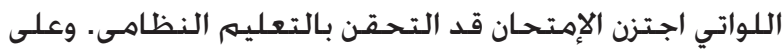

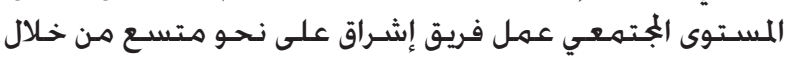

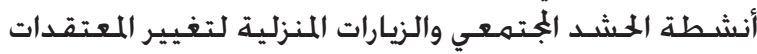

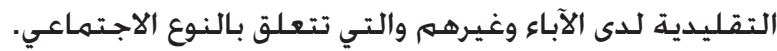

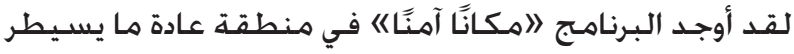

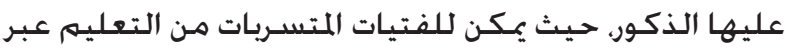

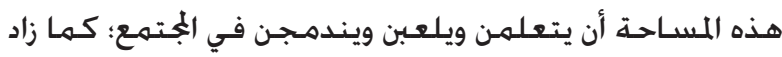
البرنامه من مشاركة الفتيات المجتمعية وعزز مكانتهن.

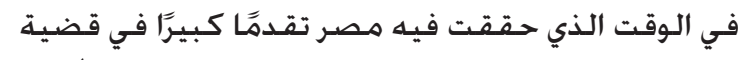

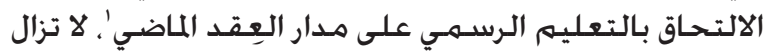

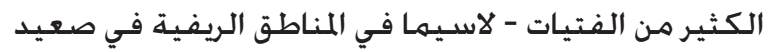

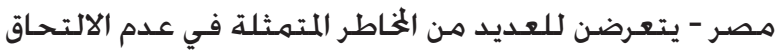

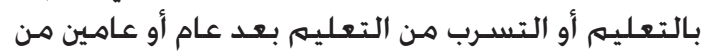

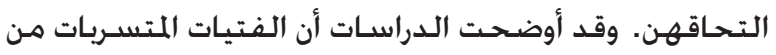

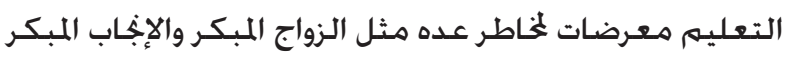

وسـوء الحالة الصحية وكذلك الفقـر المتوارث عبر الأجيال.

واستجابة لهذه الاحتياجات، قام مجلس السـكان الدولى

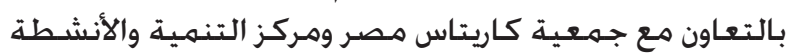

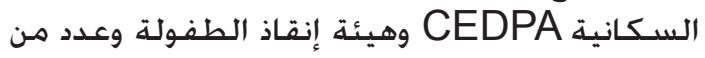

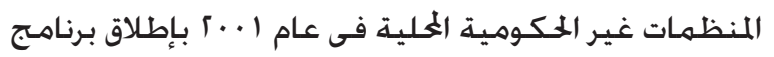

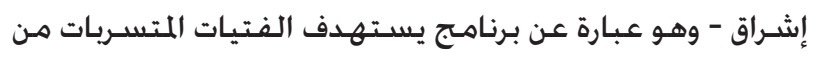

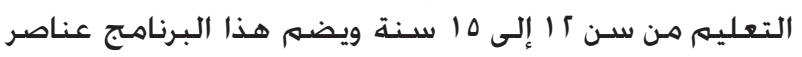

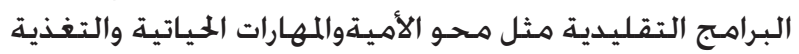
بالإضافة الى بعض العناصر المبتكرة مثل الرياضة البدنية

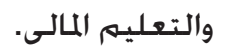

وقد اقيمت فصول إشـراق في مراكز الشـباب، وهى أماكـن

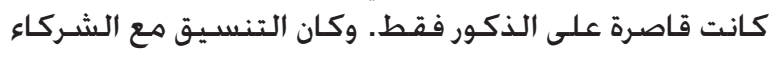

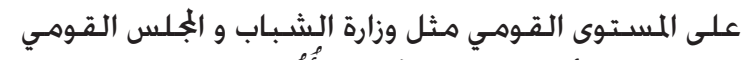

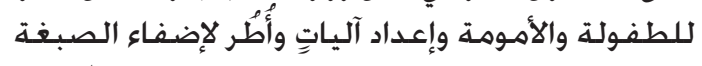

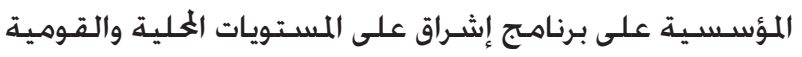

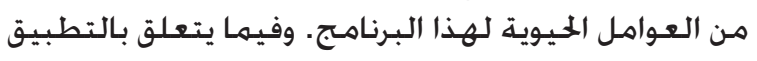

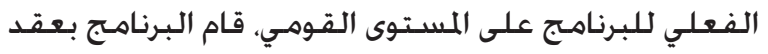

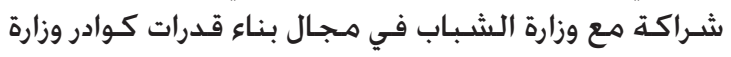

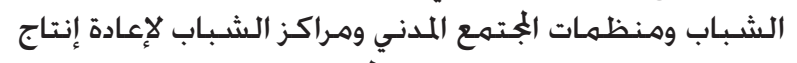

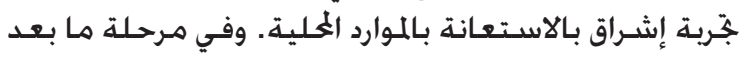

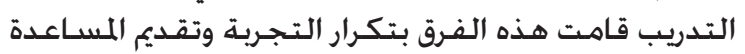

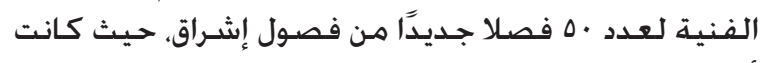

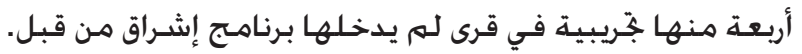




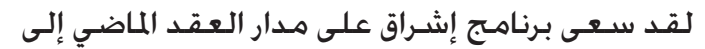

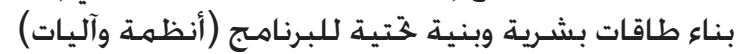

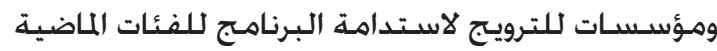

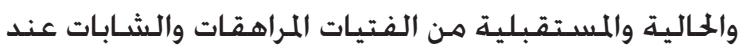

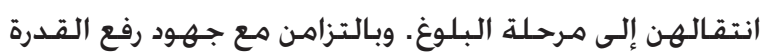

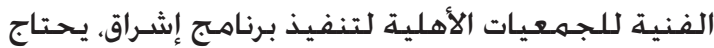

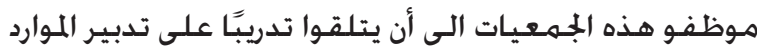

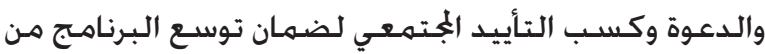

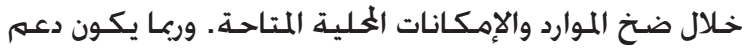

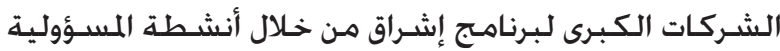

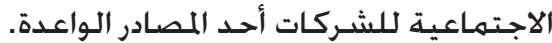

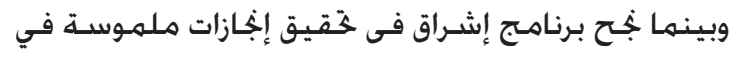

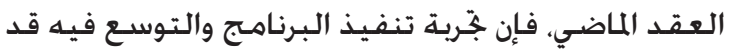

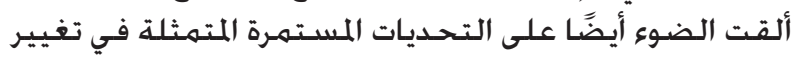

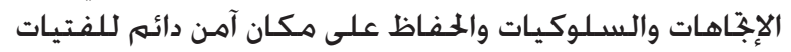

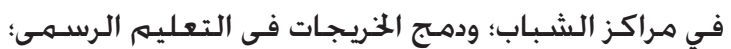

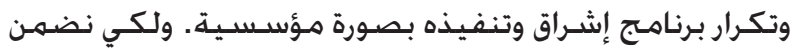

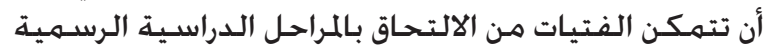

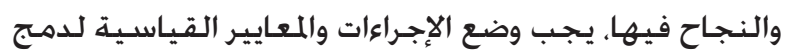

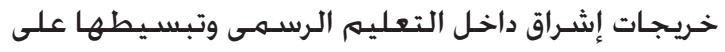

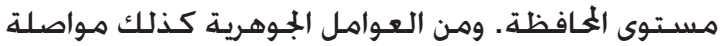

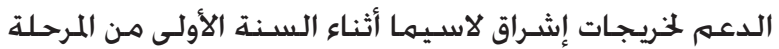

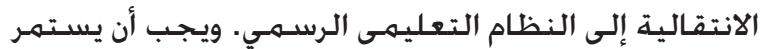

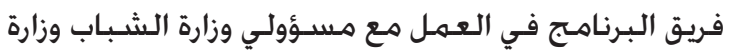

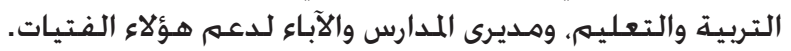

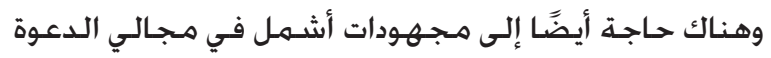

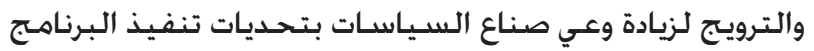

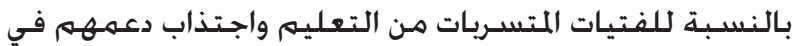

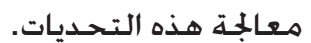





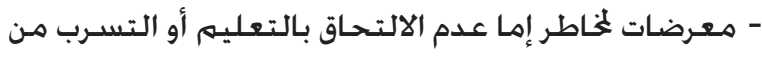

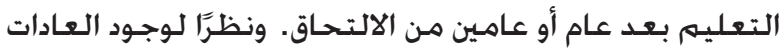

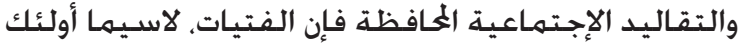

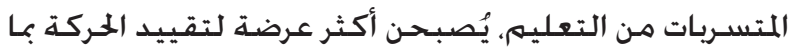

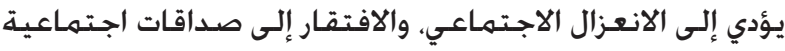

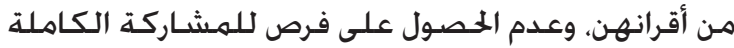

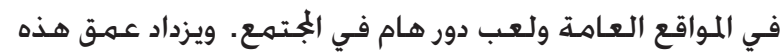

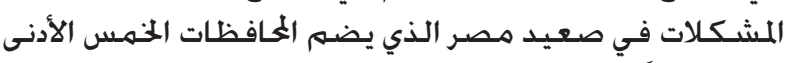

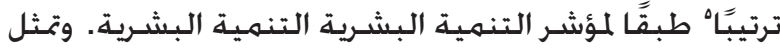

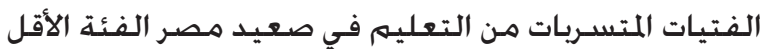

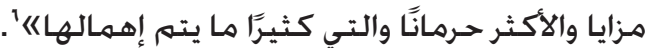

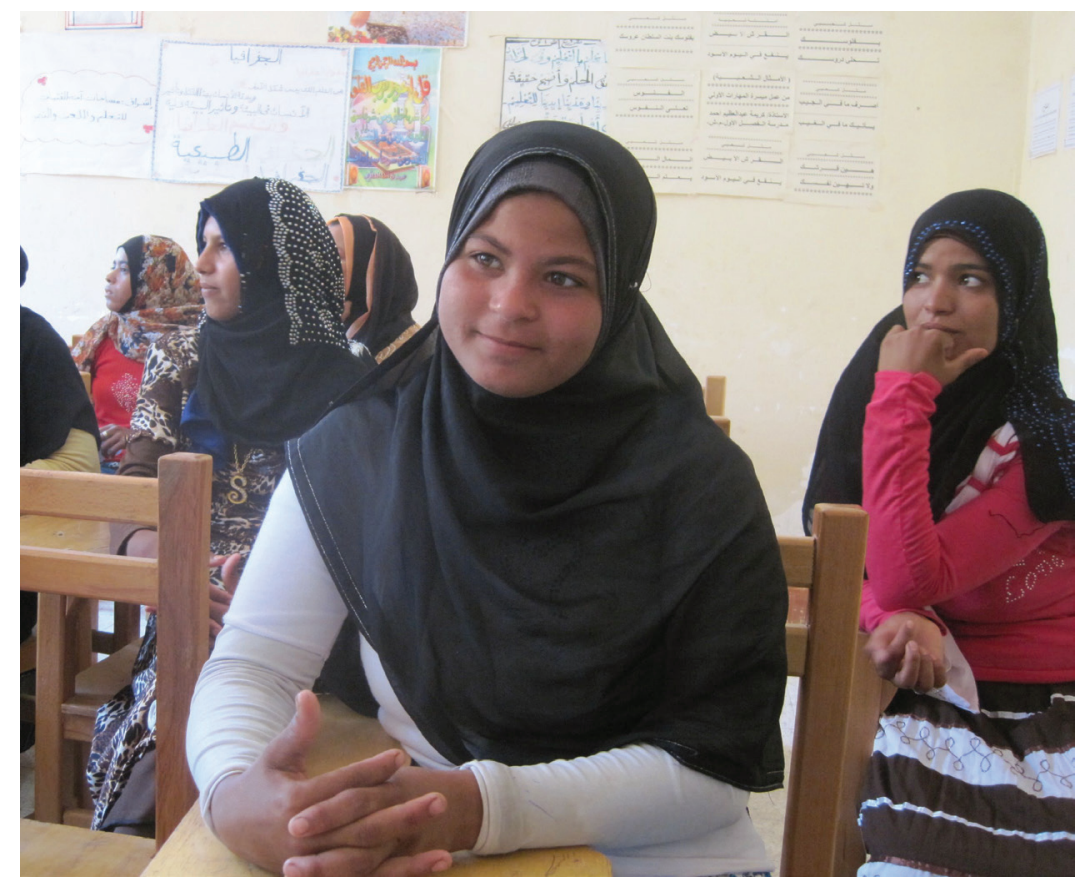

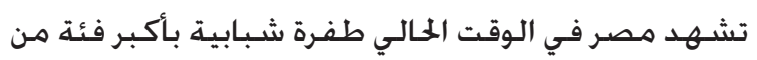

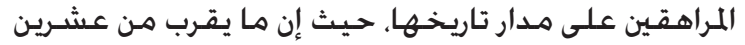

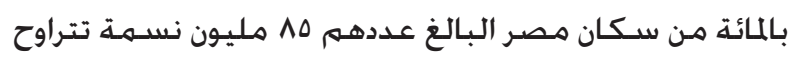

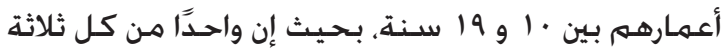

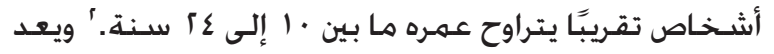

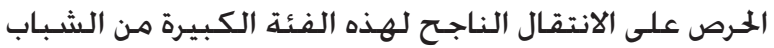

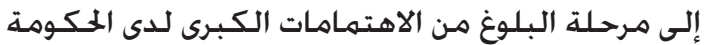

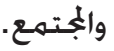

وتشـير الأبحاث المتعـمقـة التي أجـراهـا مجلسلس السـكـان

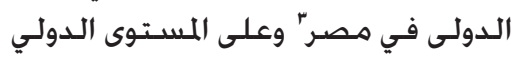

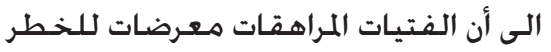

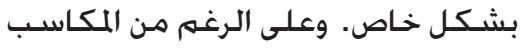

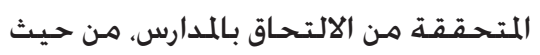
التنـمية الصحية والاقتصـادية، لا تزال

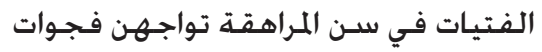

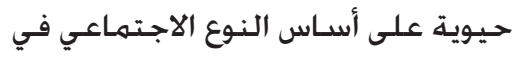
النواحي الدراسيـة والصحية والمعيشية الصية.

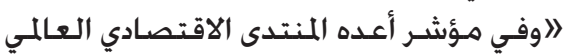

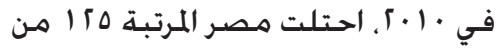
مجسموع · با دولة في زيادة حسجم التمييز

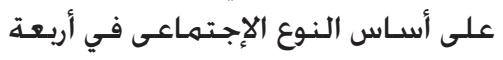

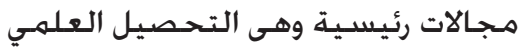

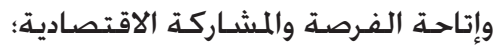

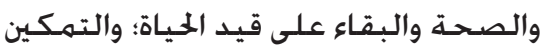

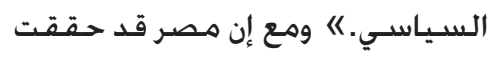

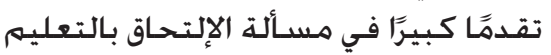

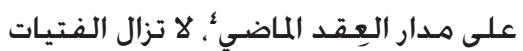

http://www.prb.org/Articles/2011/youth-egypt-revolt.aspx?p=1

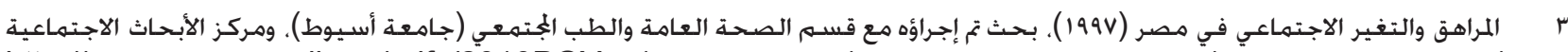

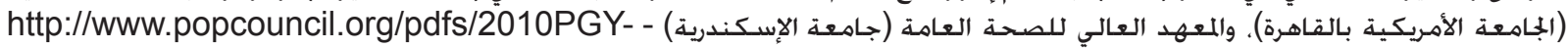
(SYPEPrelimReport.pdf

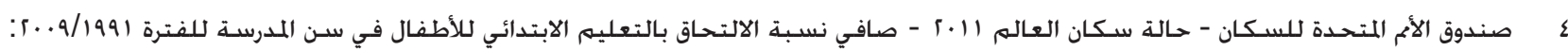

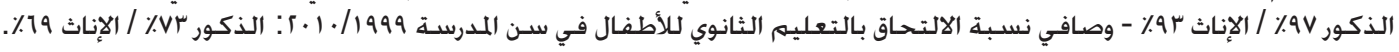

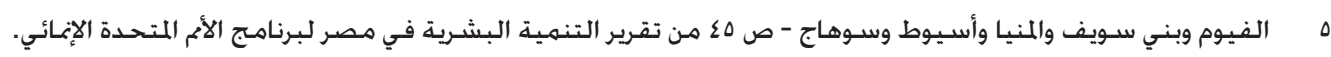

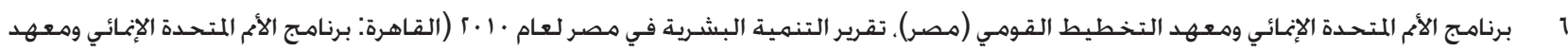




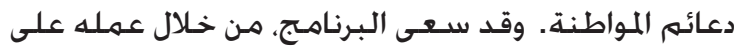

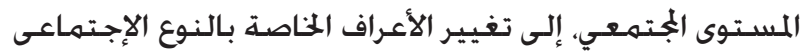

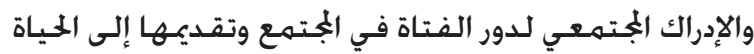

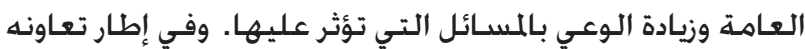

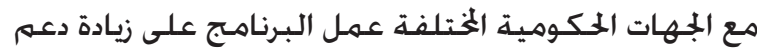

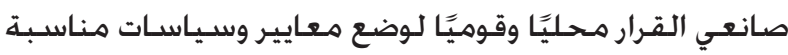

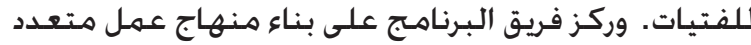

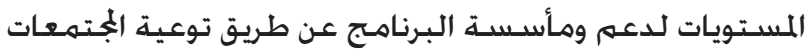

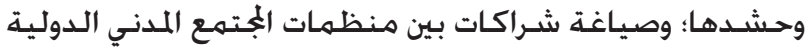

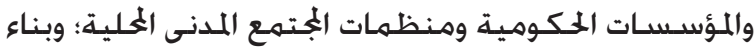
قدرات الشـركاء والمنسقين المحليين لتطبيق البرنامه.

ولقد مر ما يزيد على عقد من الزمن على إطلاق برنامج

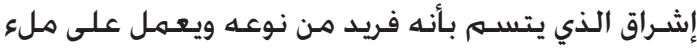

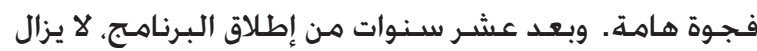

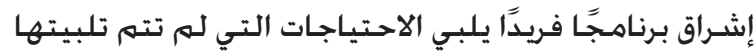

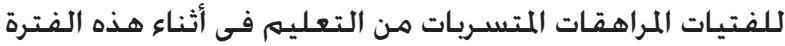

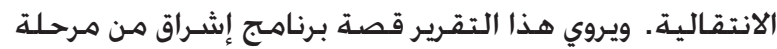

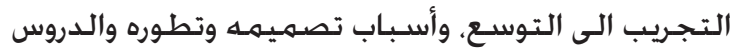
المستفـادة منـه

\section{المرحلة التجريبية (1 . + -" . +ז)}

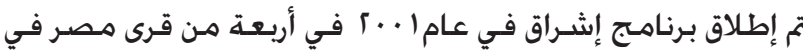

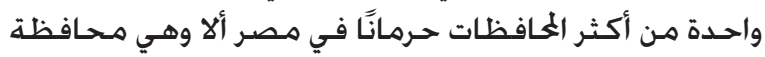

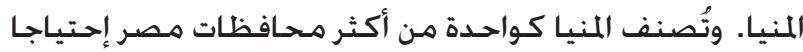

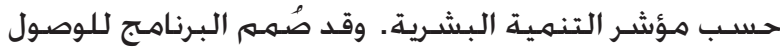

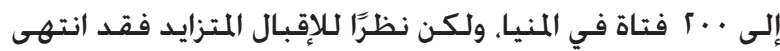

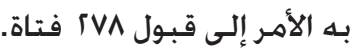

\section{محتـوى البرنامج}

لقد ضم برنامج إشـراق عناصر البرامج التقليدية بالإضافة

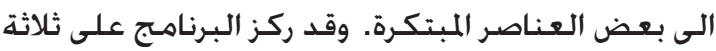

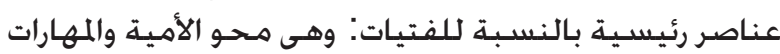

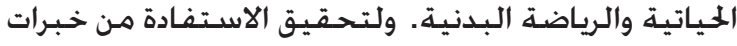

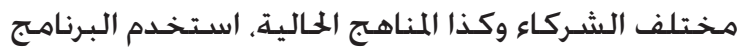

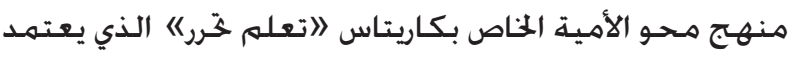

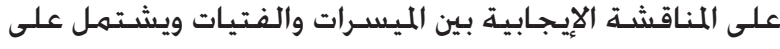
قواعد اللغة العربية (النحو) والمفردات والتراكيب والإنشـاء

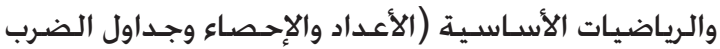
والجمع والطرح والضرب والقسـمة والكسـور، وما إلى ذلك).

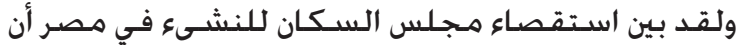

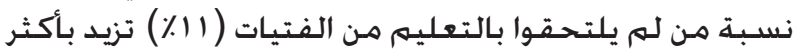

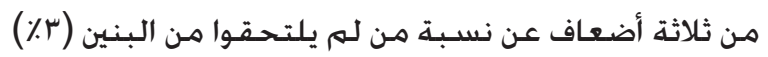

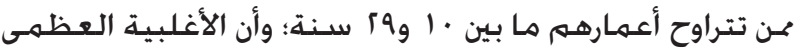

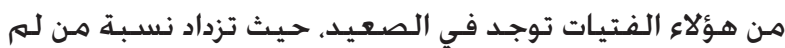

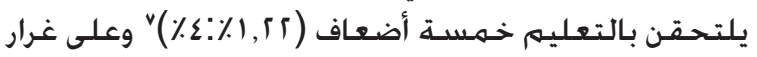

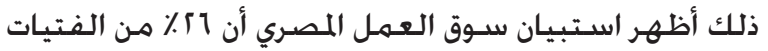

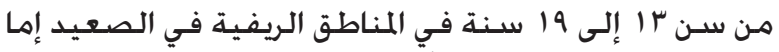

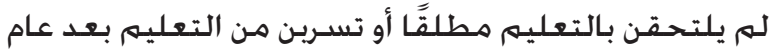

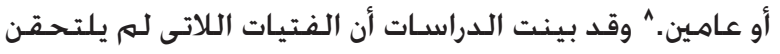

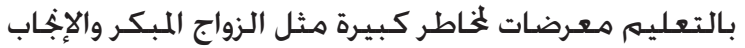

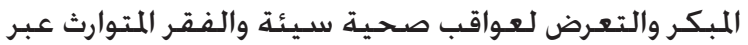

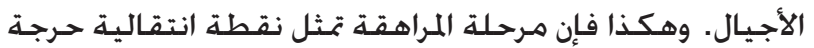
للفتيات المتسـريات من التعليه.

وقد جرت العادة أن يتهم تصميم العديد من برامج التنمية

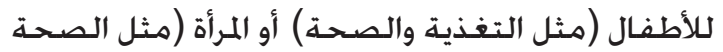

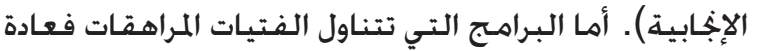

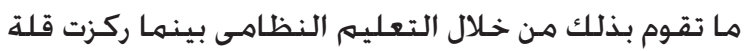

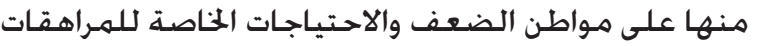
المتسـريات من التعليم في هذه المرحلة الانتقالية الحرجـة.

\section{منهـج إشـراق}

واستجـابة لهذه الإحتياجـات قام مجلس السـكان الدولى

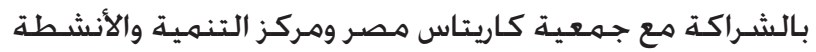

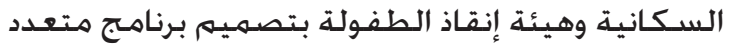

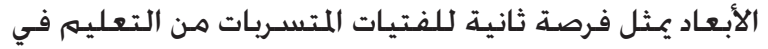

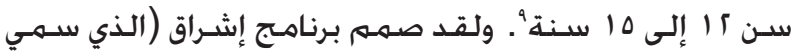

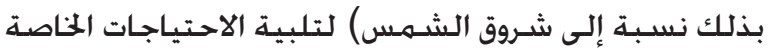

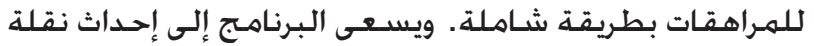

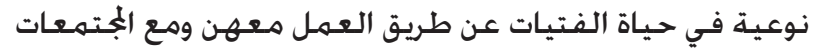

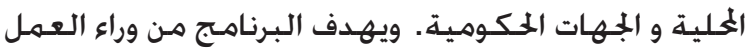

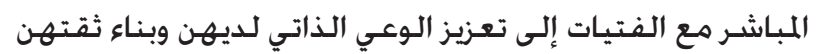
بأنفسهن.

وقد عمل البرنامج على إيجاد لأماكن آمنة " مناسبة

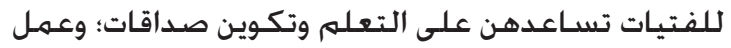
البرنامج على تحسين معرفتهن العملية بالقراءة والكتابة التحنية

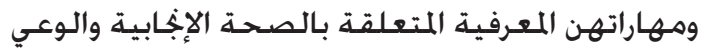
بحقوقهن: وشـجع على مواصلة التعليه في المدرسـة: وأرسى اللـى

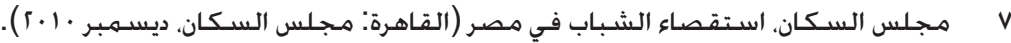

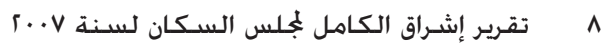




\section{تكـوين الشـراكات}

وإدراكًا من الشـركاء الأريع من منظمات الجُتمع المدني بأهمية

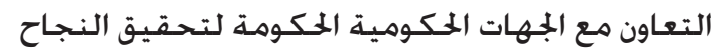

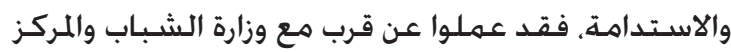
القومي للطفولة والأمومة ووزارة الدولة لشـؤون الأسـرة

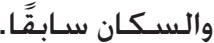

كمما عمل المشـروع مع الجهات المحلية على مستوى المحافظة

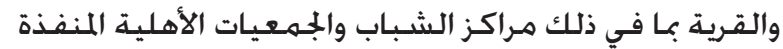

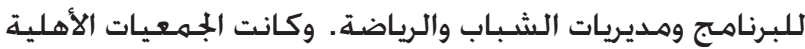

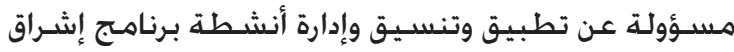

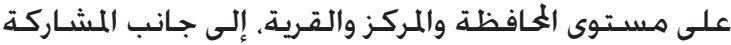

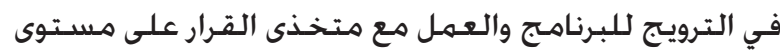

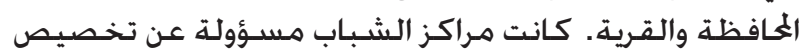

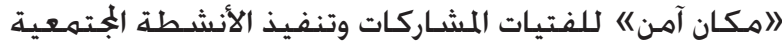

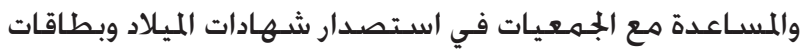
خقيق الشخصية للفتيات والعمل مع مديريات التربية التحنية

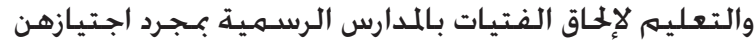

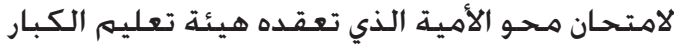

\section{تعيين الميسـرات}

يقوم بالتدريس داخل فصول إشـراق خريجات الثانوية العامة

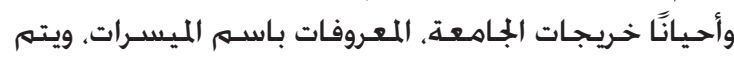

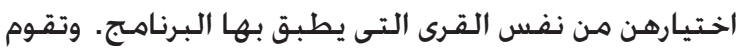

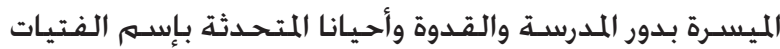

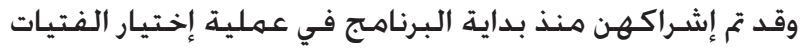

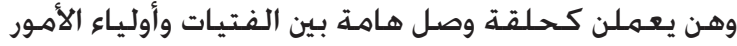

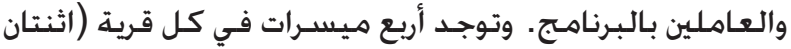

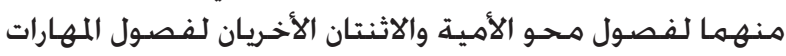

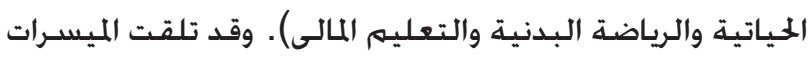

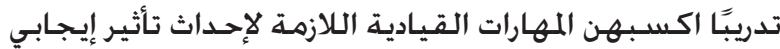

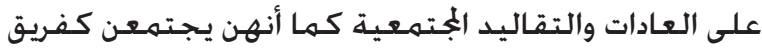

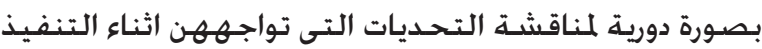

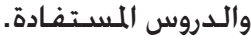

\section{تعبئتة المجتهمع}

وإدراكًا من البرنامج بأن المراهقات لسـن صانعات لبـات للقرارات

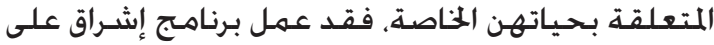

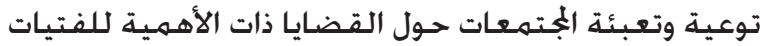
المراهقات. فقد عقد فريق البرنامج لقاءعات وأنشطة الأعة حوار

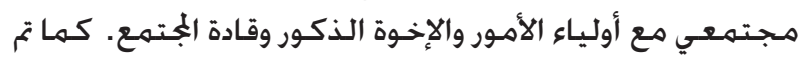

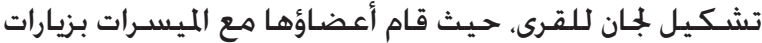
منزلية للاطمئنان على الفتيات والتواصل مع أولياء أمورهن.
كما اشتمل على منهج المهارات الحياتية لآفاق جديدة) الذى الذي

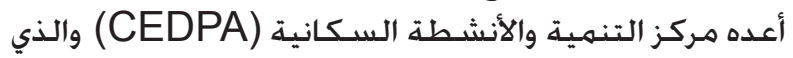

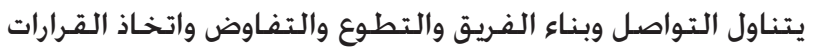

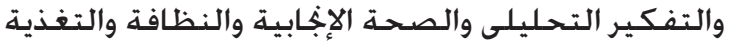

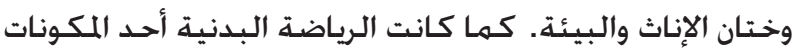

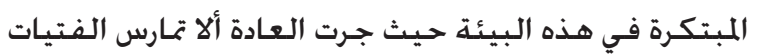
الرياضة. بدأ البرنامج بتعليهم الفتيات العناصر الأسـاسية التعاسية

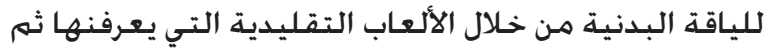

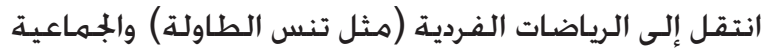

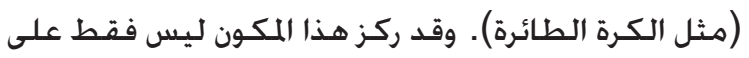

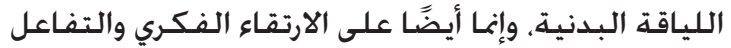

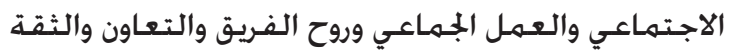

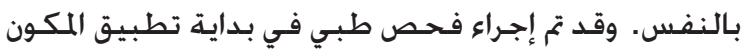

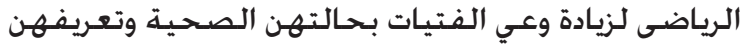

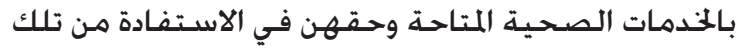

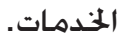

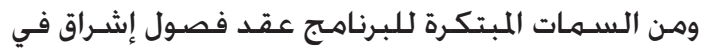

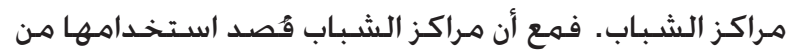

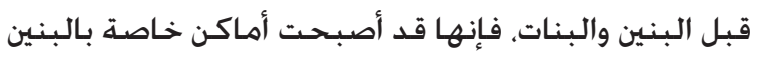

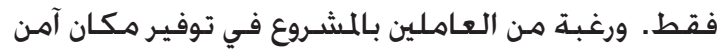

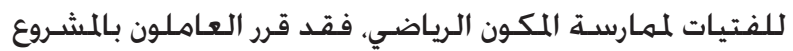

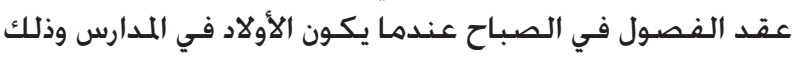

لطمأنة أولياء الأمور بأن مركز الشباح ابـاب سيكون مكانًا آمنًا

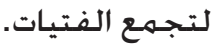

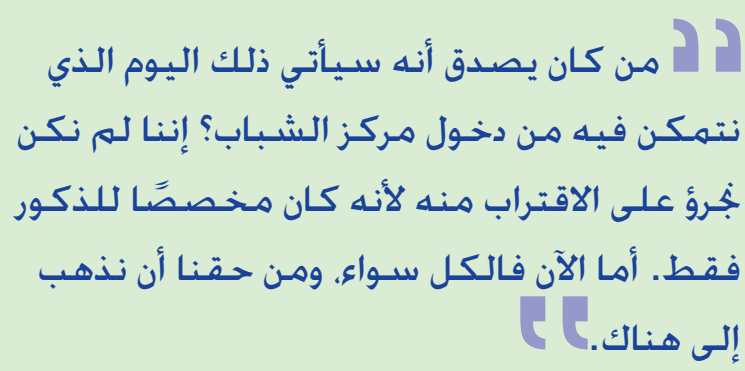
- إحـدى الميسـرات في برناهـج إشـراق

\section{اختيار القـرى}

لقد كان من أهم معايير إختيار القرى للمشاركة في برنامجاج

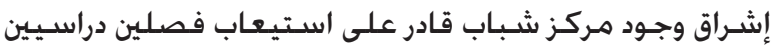

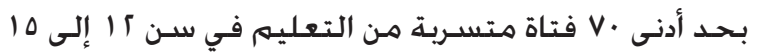

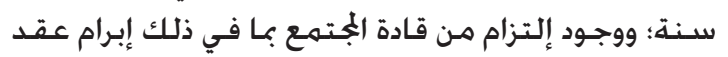

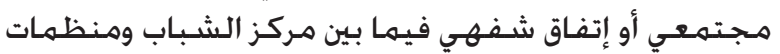

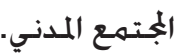


وهو يواصل تطوره، بحيث تبنـي كل مـرحلة على دروس المرحلة

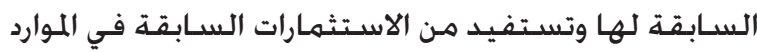

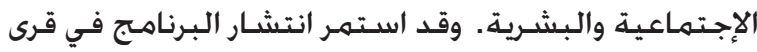

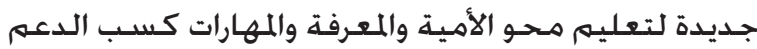

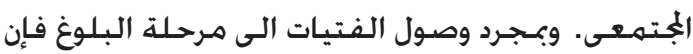

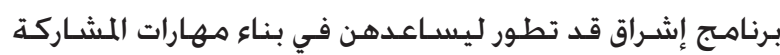

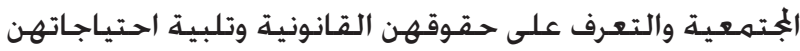
الاقتصادية.

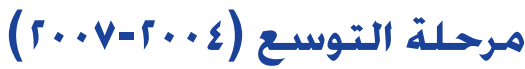

للاسـفــادة من الدروس المسـتخلصـة مـن المرحلة التجـريبية،

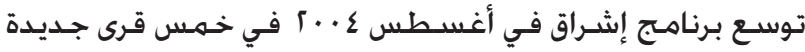

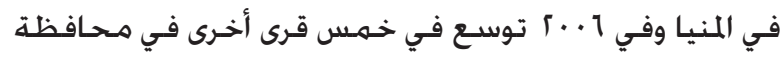

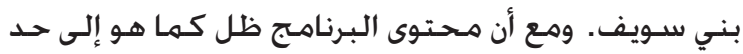

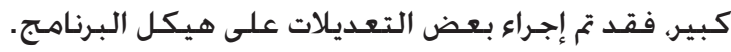

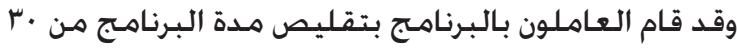

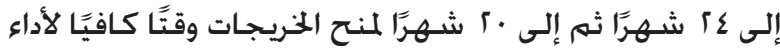

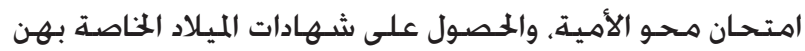

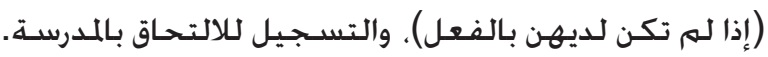

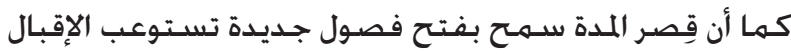

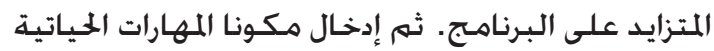

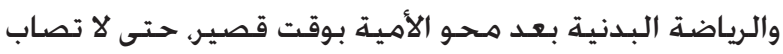

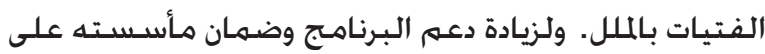

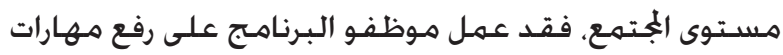

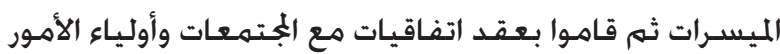

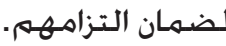

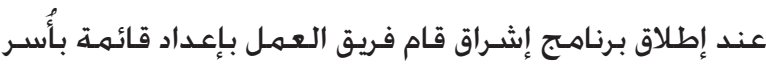

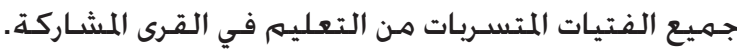

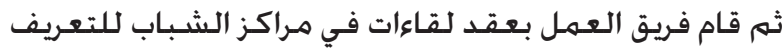

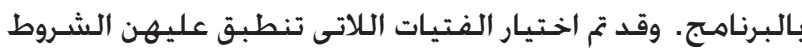

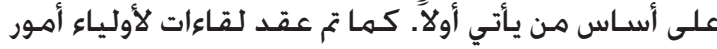

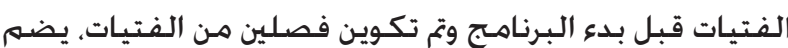
كل فصل · r فتاة، في كل قرية.

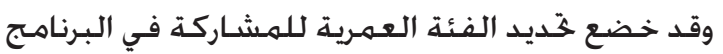

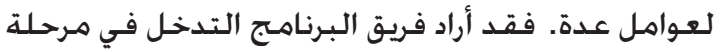

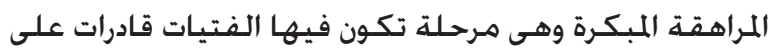

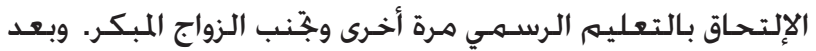

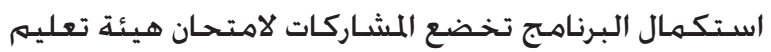

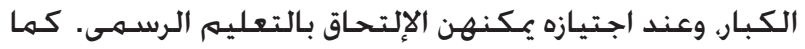

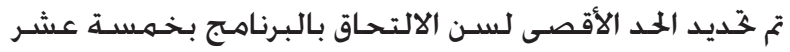

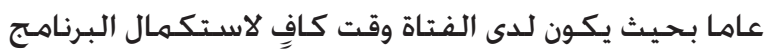

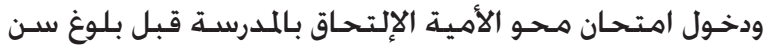

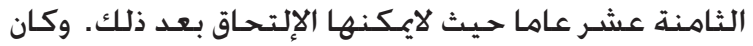

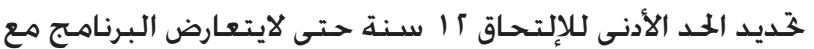

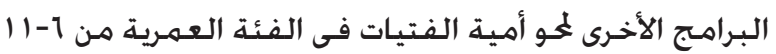

تنفيذ البرناهـ

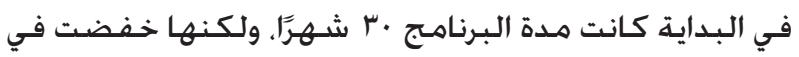

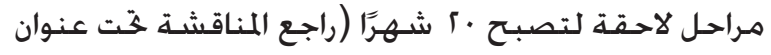

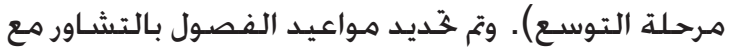

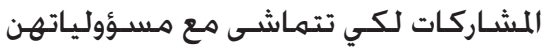

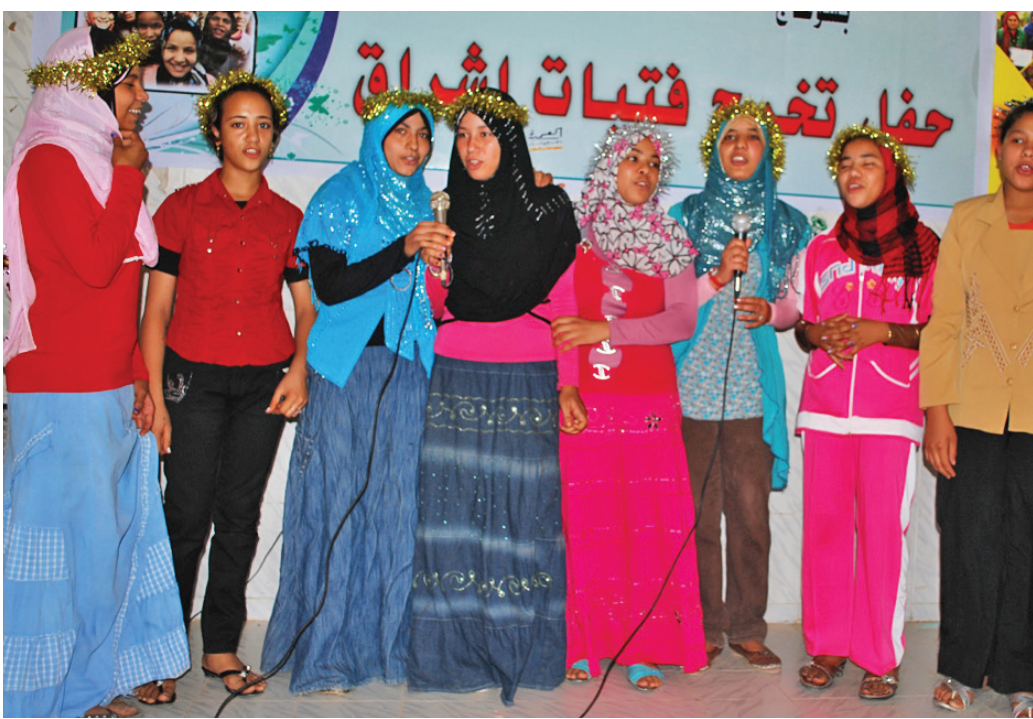

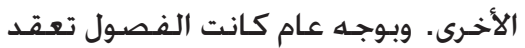

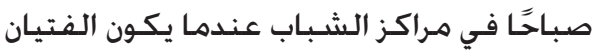

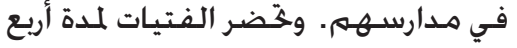
سـاعات في اليوم بمعـدل أربع مـرات أسبـوعيًا.

\section{تطور برنامج إشـراق

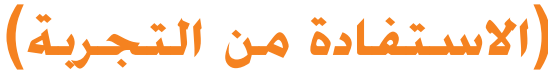

مر برنامـج إشـراق بثلاثة مراحل إضـافية منـذ

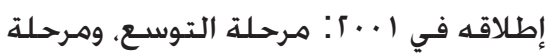

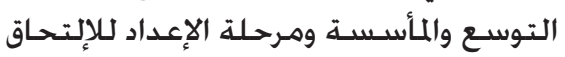
بالتعليهم الرسـمى. ومنـذ إطلاق البرنامـج 
تنفيذ البرنامسج بموارد محلية؛ من أجل تبني سياسـات وممارسـات المبات

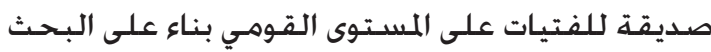

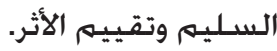

وقد تمت إضافة مكونين آخرين إلى المنهج للفتيات في هذه المها

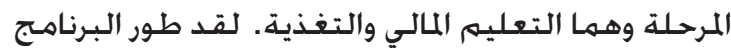

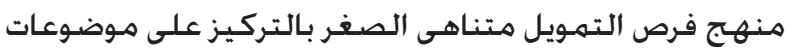

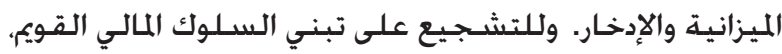

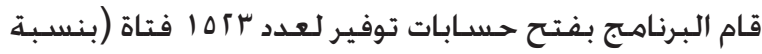

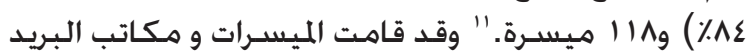

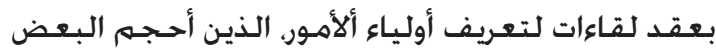

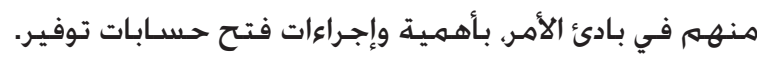

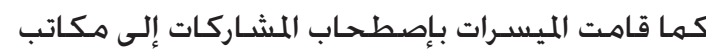

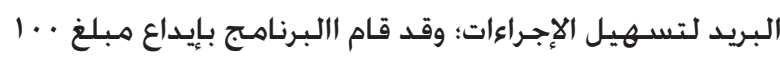

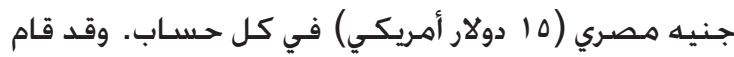

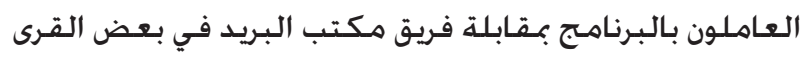
للمساعدة في الحصول على دعمهم وتعاونهم.

وبالنسبة لمكون التغذية، قام بنك الطعام المصري بتزويد

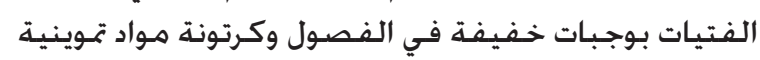

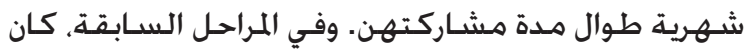

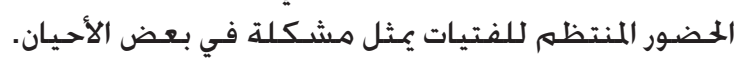

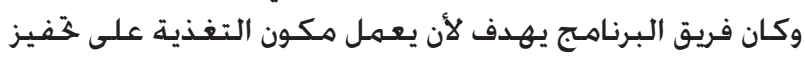

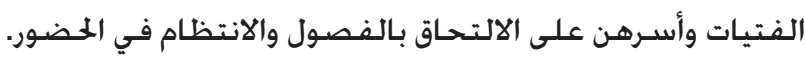

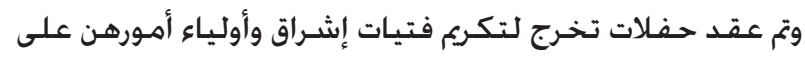

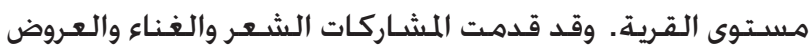

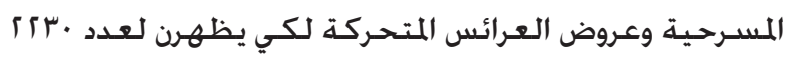

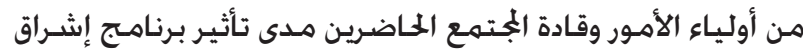

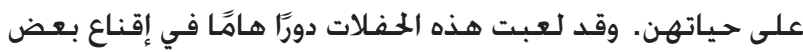
الآباء بإلحاق بناتهم بالتعليه ولعه الرسـمي.
وبالنسبة لهذه المرحلة والمراحل اللاحقة، قام فريق البرنامج

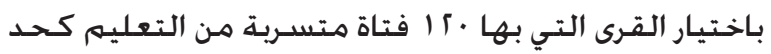

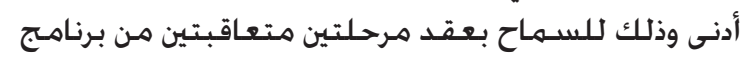

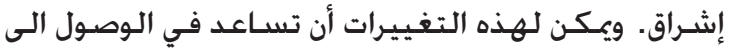

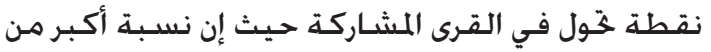

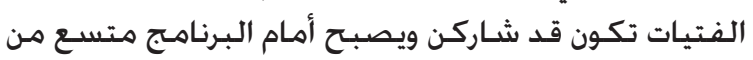

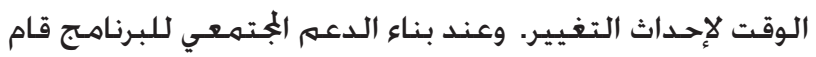

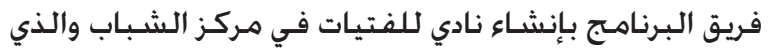

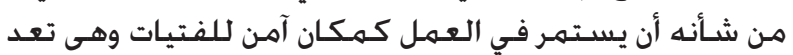
خطوة نحو إستـدامة البرنامـج.

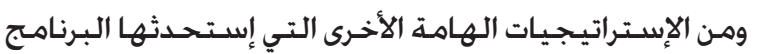

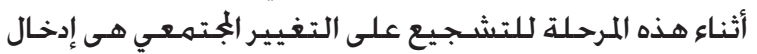
برنامج "رؤى جديدة) من قبل مركز التنمية والأنشطة

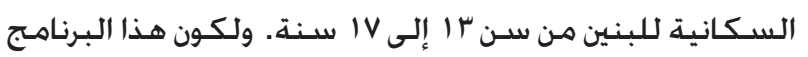

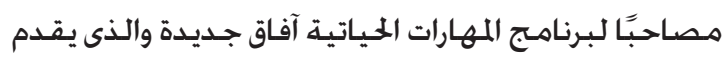

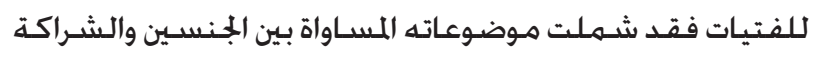

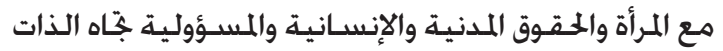

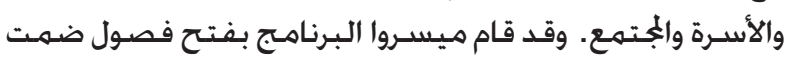

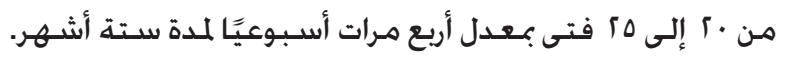

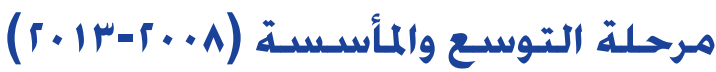

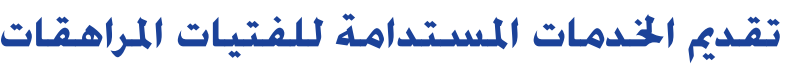
في المناطق الريفية. '

وفي نوفمبر ^^• • آم البدء في تطبيق إشـراق في ثلاثين قرية

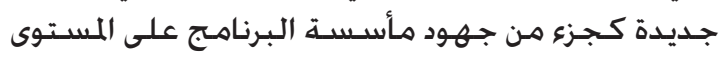

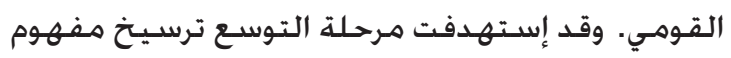

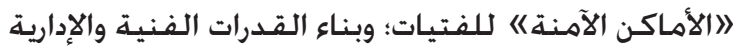

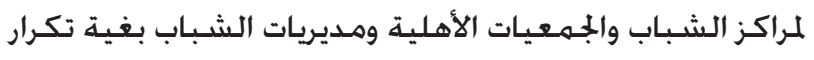

• مت تنفيذ مرحلة التوسع بواسطة مجلس السـكان بالتعاون مع كاريتاس، والفريق للتنمية، وبنك الطعام المصري وست من الجمعيات الأهلية في الفيوم

وسـوهاج وقنا.

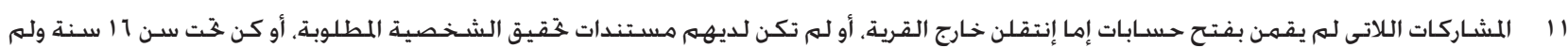
يكن معهن ولي أمر. 
كـما قـام فريق إشـراق بتـفـيذ أنشـطـة حـوار مـجــمعى في ثلاث

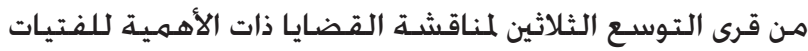

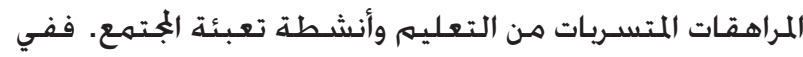

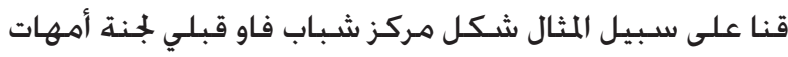

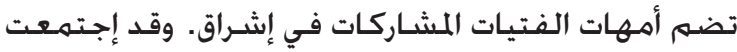

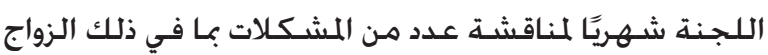

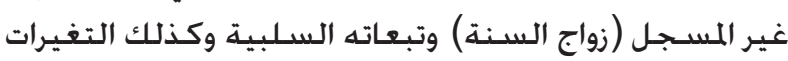

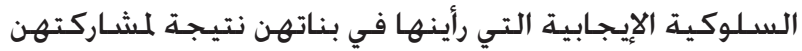

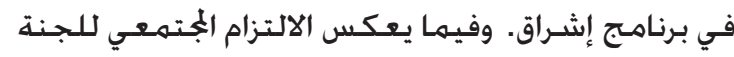

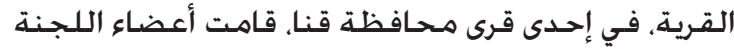

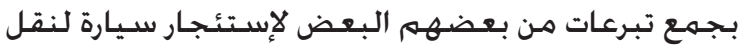

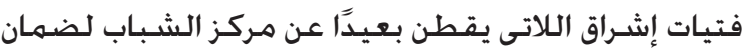
انتظامهـن في البرنامج.

وفيـما يتعلق بالتوسـع على المســوى القـومي فإن البرنامـج

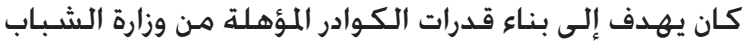

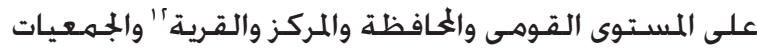

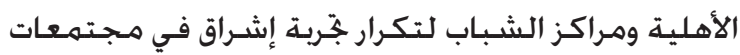

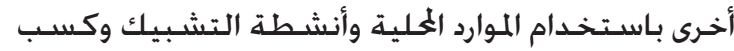

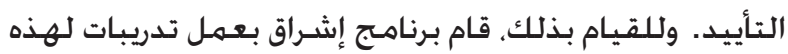

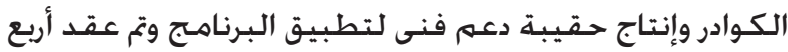

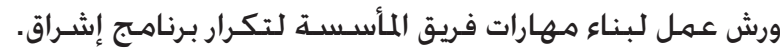

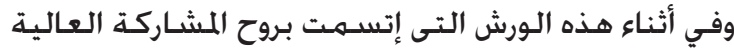

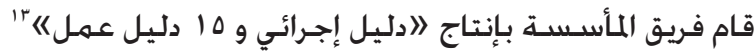

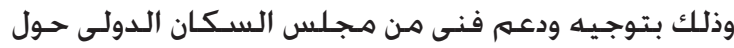

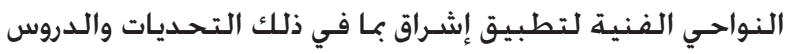

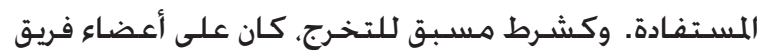

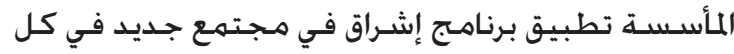

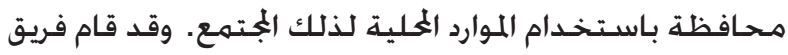

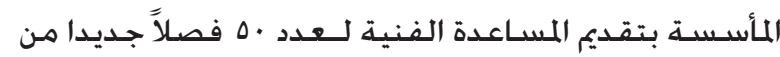

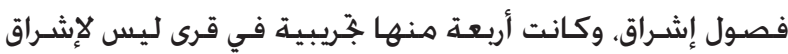

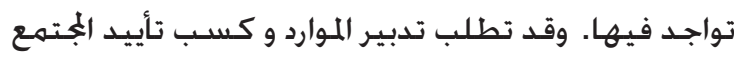
جهودا مكثثفة، بما في ذلك لقـاعات التوعيـة الجمتمعيـة والزيارات

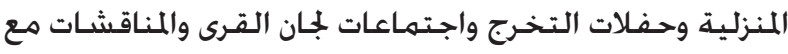
الجهات الحكومية. ونتيجـة لهذه المناقشـات،وافقت هيئة تعليه

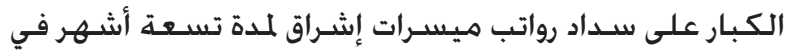

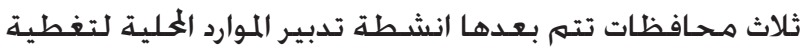

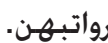

البحدول ا: مهـرجـات برنامه إشـراق فى مرحـلة التوسـع

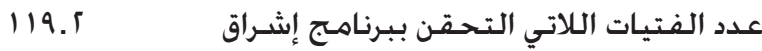

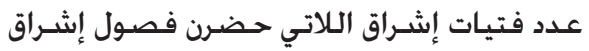

بشـكل منتظم حتى التخـرج
عدد الفتيات اللاتي تقدمن لامتحـان هيئة تعليم $1 \leq 0.1$ الكبار

$\sum \Sigma r^{\prime} .1$ عدد الفتيات اللاتي اجـزن امتحـان هيئة تعليم

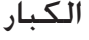

Vos

عدد الفتيات اللاتي اجـزن امتحـان هيئة تعليه

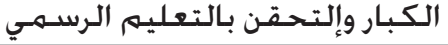

عدد الفتيات اللاتي تسـربـن مـن البرنامـج لأجل الزواج

مأسسستة برنامه إشـراق: إحـداث تغير هستـدام.

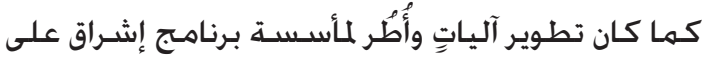

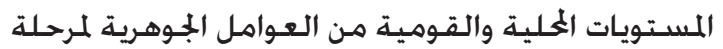

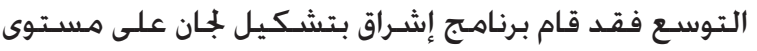

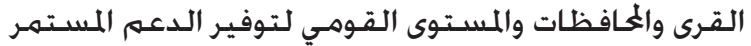

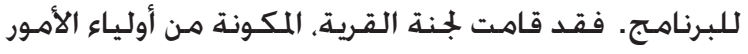

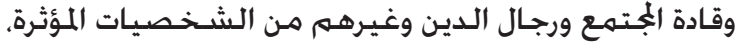

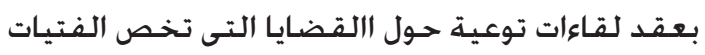

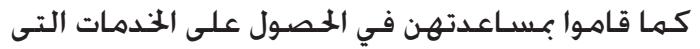

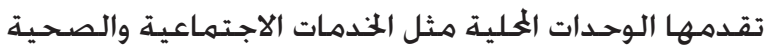

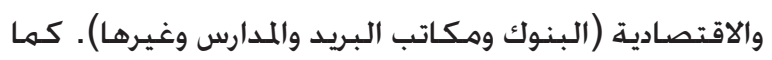

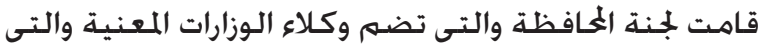

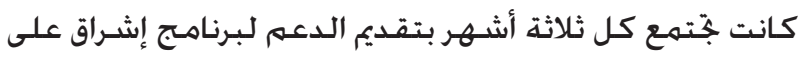
مستـوى المافافظة في أمور مثل إستـخـراج شهـادات الميلاد وإجـراء الفحـوصات الطبية.

وعلى المستوى القومي، تم توقيع مذكرة تفـاهم بين وزارة

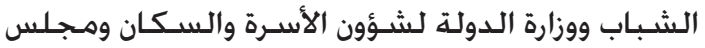

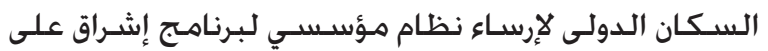

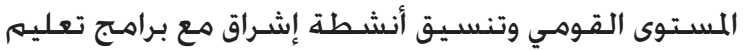

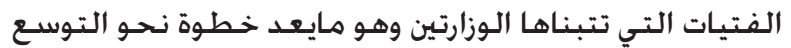

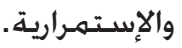


وقد إســهـدف تـدريب الحقـوق القـانونية والذي اسـتغرق ثمـانية

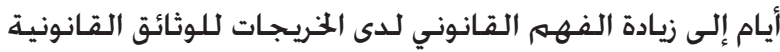

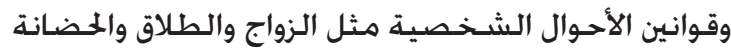

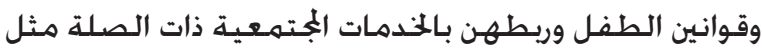

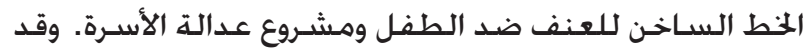

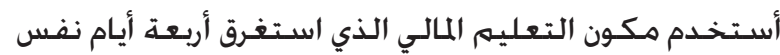

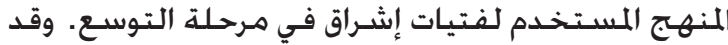
استخـدم تدريب المهارات المهنية وحدات PlaNet Finance

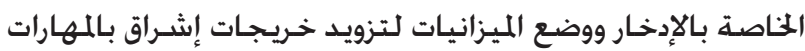

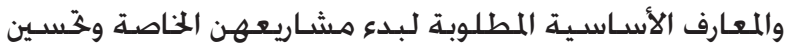

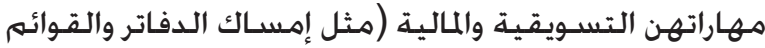
المالية وقوائم الدخـل والتدفق النقـدي والتسـويق والتفـاوض).

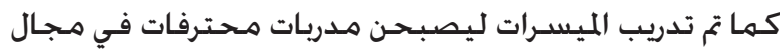

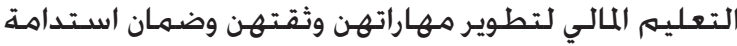

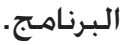

وما أن اســكملت الفتيـات بـرنامـج إثـراق واجتـزن امتـحـان

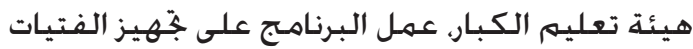

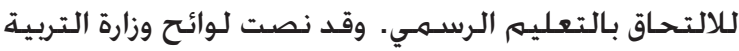

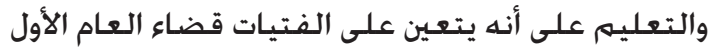

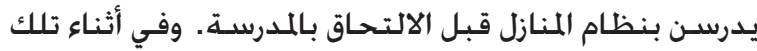

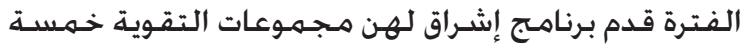

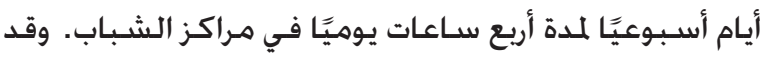

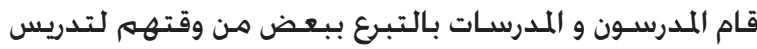

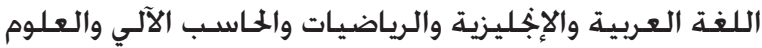

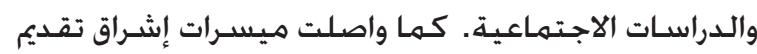

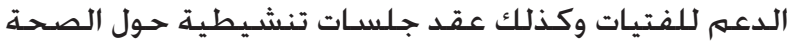

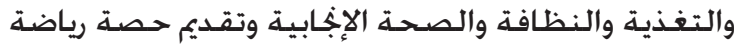

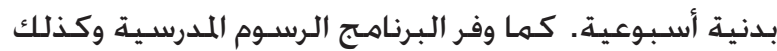

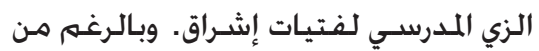

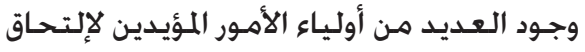

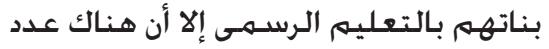

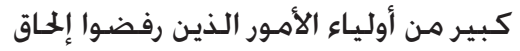

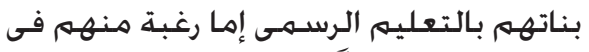

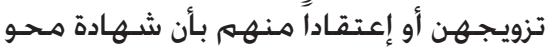

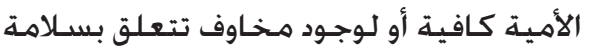

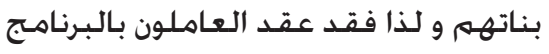

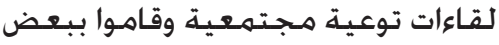

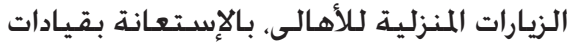
الجمتـمع والنـماذج الإيجابية من أولياء الأمهور

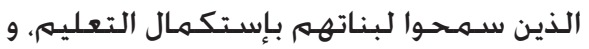

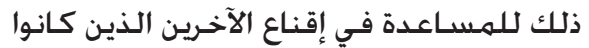
أكثر إحجـامًا عن إسـتكـمال تعليهم بنـاتهـم.

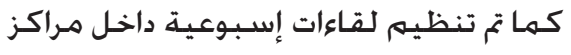

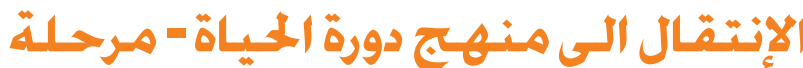

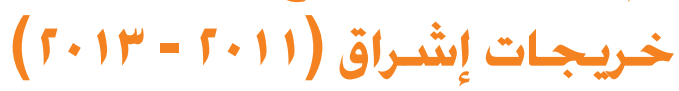

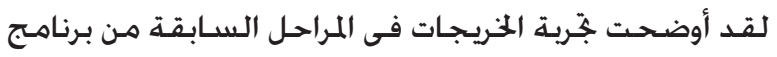

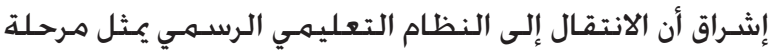

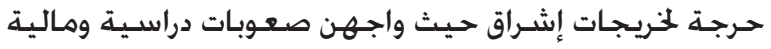

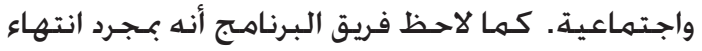

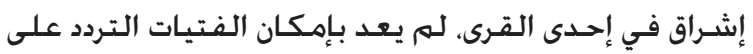

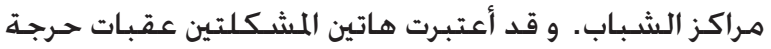

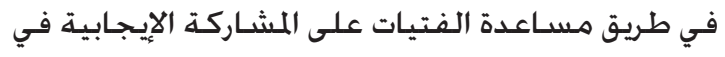

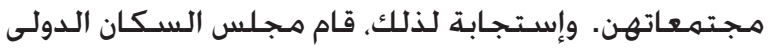

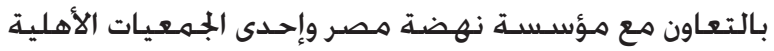

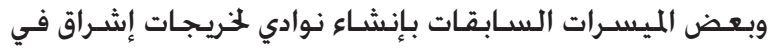

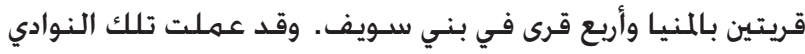

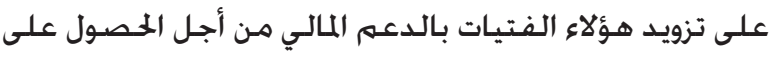

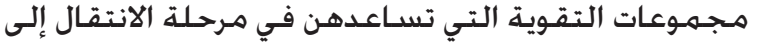

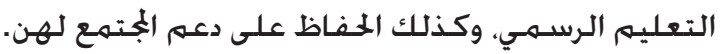

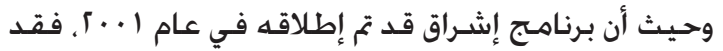

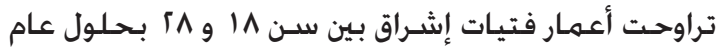

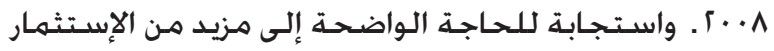

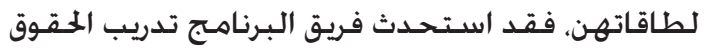

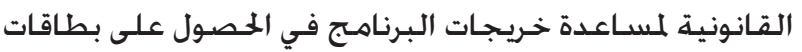

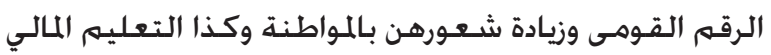

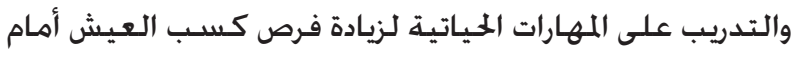

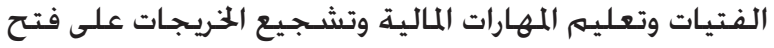
حسـابات توفير.

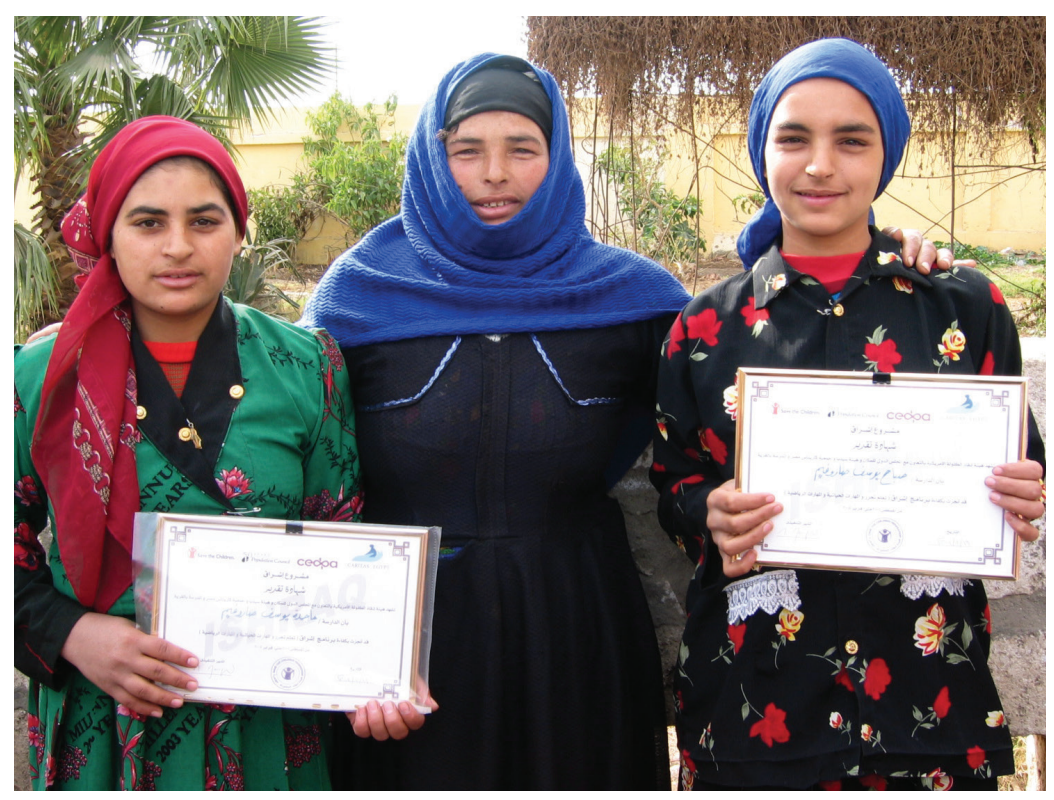




$$
\begin{aligned}
& \text { حل كل شيء في الدنيا بيعتمد على القراءة؛ }
\end{aligned}
$$

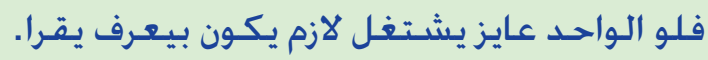

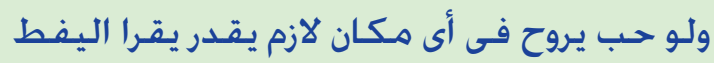

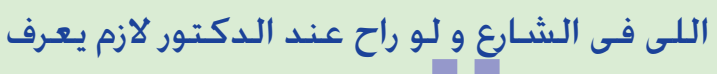

$$
\begin{aligned}
& \text { - إحـدى فتيات إثــراق، الجـزازرة }
\end{aligned}
$$

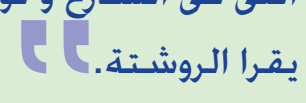

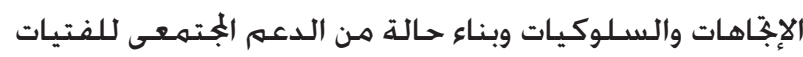

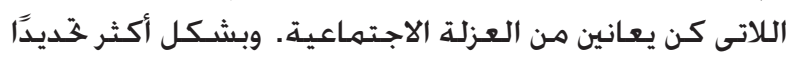
أظهرت مشاركات إشـراق مايلى:

\section{تحسن نتائسج المعرفة والإلمام بالقراءة والكتابة}

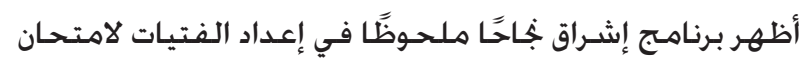

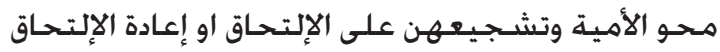

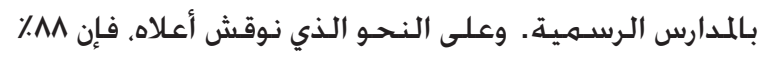

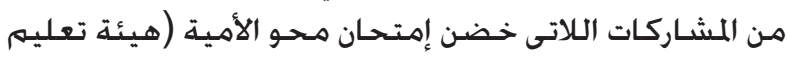

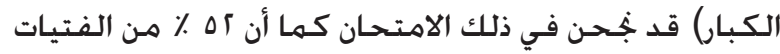

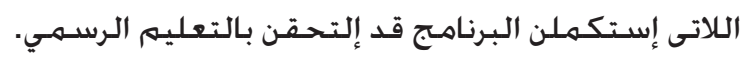

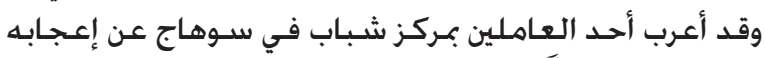

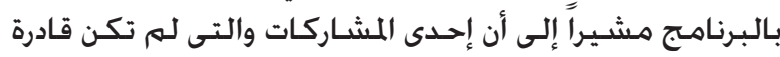

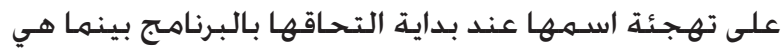
الآن طالبة بالصف الثاني الإعدادي.

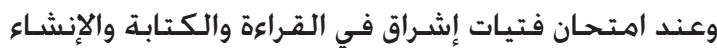

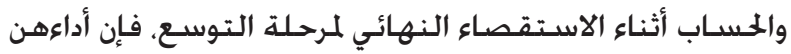

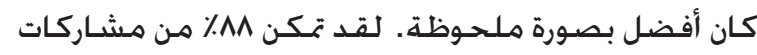

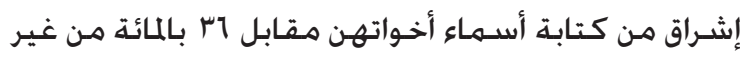

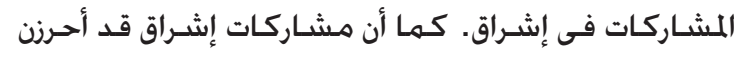

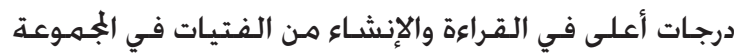

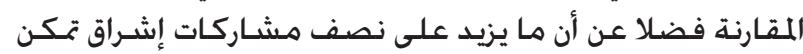

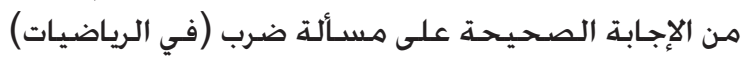

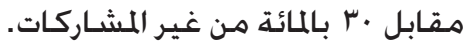

\section{معـرفت وإجناهـات أفضل نـــو تمكين الفتاة}

كما كان لإشـراق أثر إيجابي، على معرفة المشـاركات وإبجاهاتهن المتعلقة بالصحة الإبنابية والزواج والإنجاب وختان الإناث المثان

$$
\text { يتحـكـم في إذا كنت متعلمة فما مفيش حـد يقدر }
$$

- إحدى فتيات إشـراق بقرية شـدموة
الشباب لفتيات إشـراق اللاتى لهم يتمكن من الإلتحاق بالتعليه

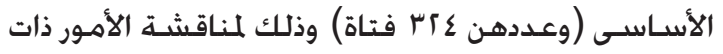

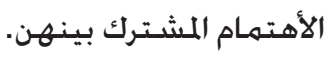

\section{شَفيـز التخيـر: إبجـازات برنامهج إشـراق}

وعلى مدار الســوات العشـر الماضية تمكـن برنامج إشـراق

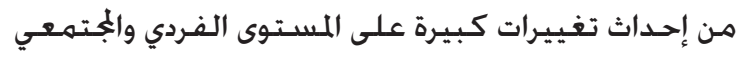

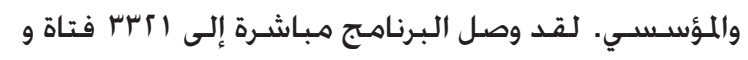
IVVD

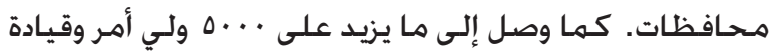

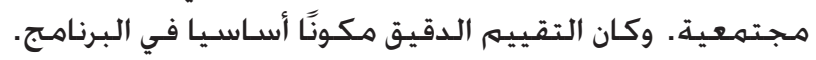

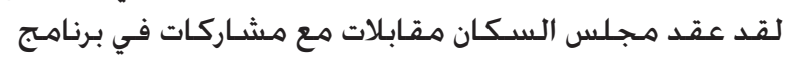

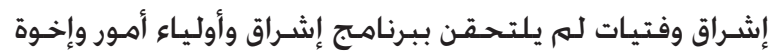

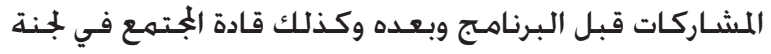

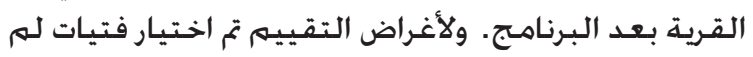

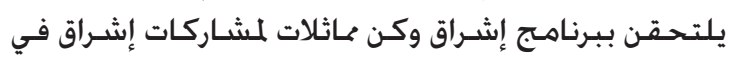

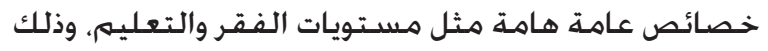

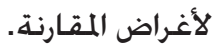

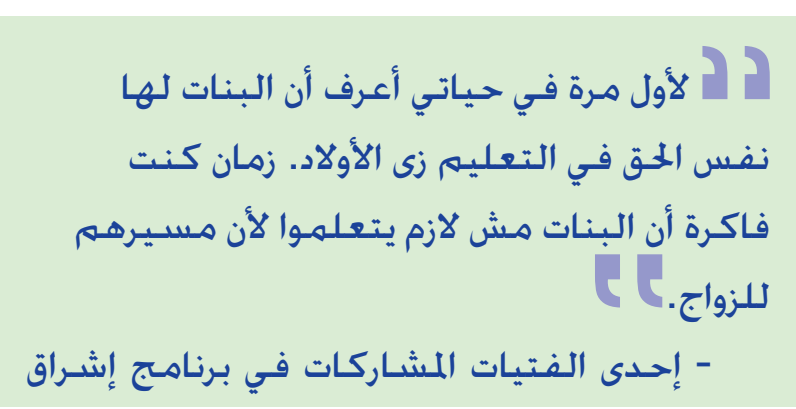

وقام التقييم بمقارنة فتيات إشـراق و الفتيات اللاتى لهم يلتحقن

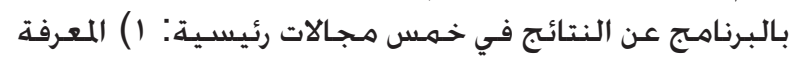

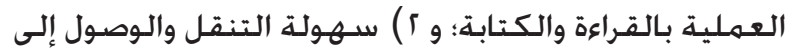

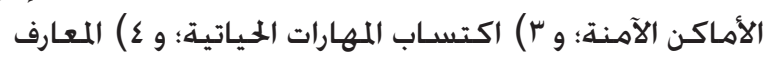

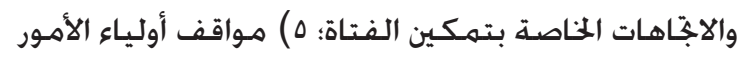

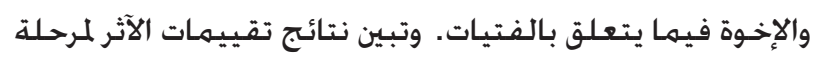

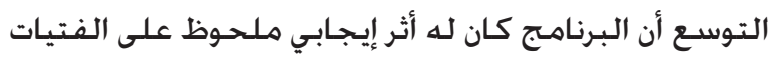
المشـاركات وعلى الجمتمعات.

\section{المستوى الفردي - تمكين الفتيات}

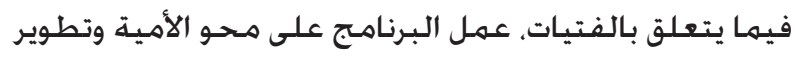

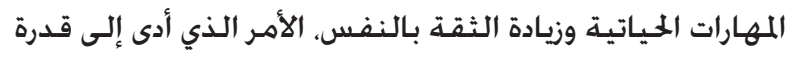

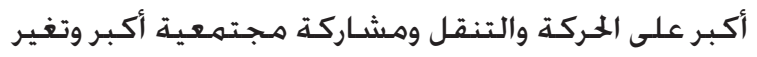


كما كانت مشاركات إشـراق أكثر رغبة في تأخير الزواج

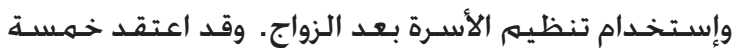

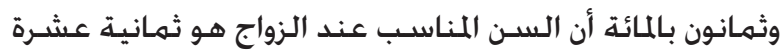
سـنة أو أكبر مقابل لآل بالمائة من غير المشـاركات.

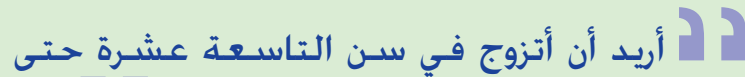 أكـون قادرة على خَمـل مسـؤوليات الزواج. - إحـدى فتيات إشـراق، شـدموة}

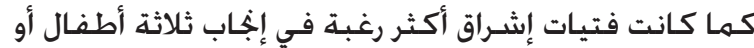

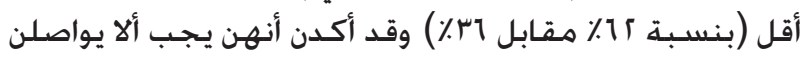

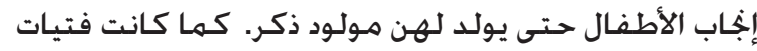

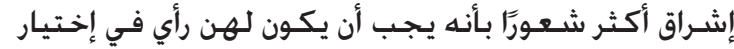
الشـخص الذي سـوف يتزوجنه.

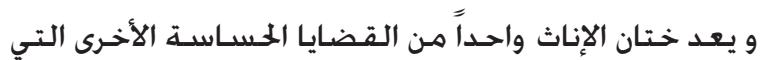

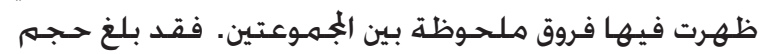

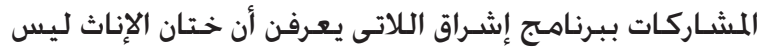

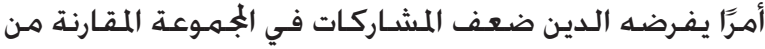

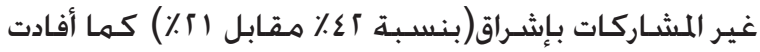

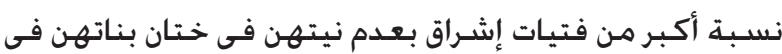
المستقبل (1 ٪ مقابل • (1\%).

\section{اكتساب المهارات الحياتية}

و قد سـاعد إشـراق على المهارات الحياتية قد سـاعد الفتيات

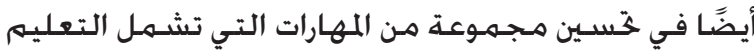

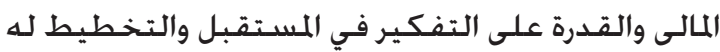

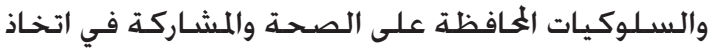

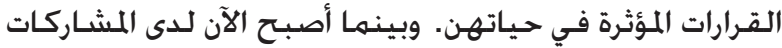

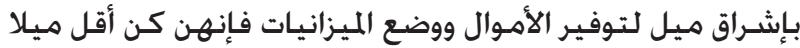

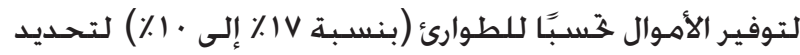

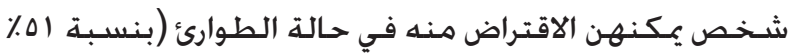

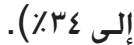

كما أن المشاركة في برنامج إشـراق قد سـاعدت الفتيات على

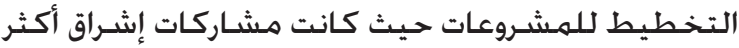

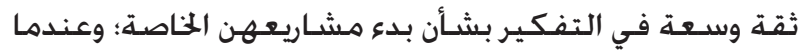

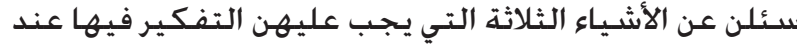

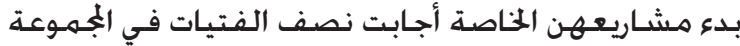

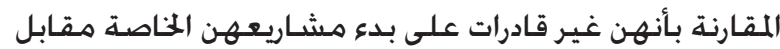

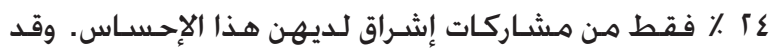

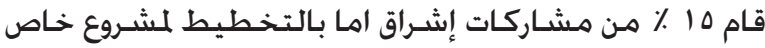

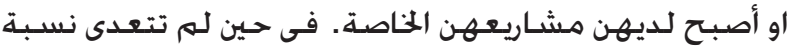

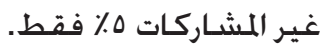

\section{شـكل ( ) أسلوب قابلية مطابقة النتائج فى إشـراق:

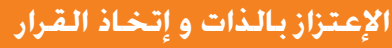

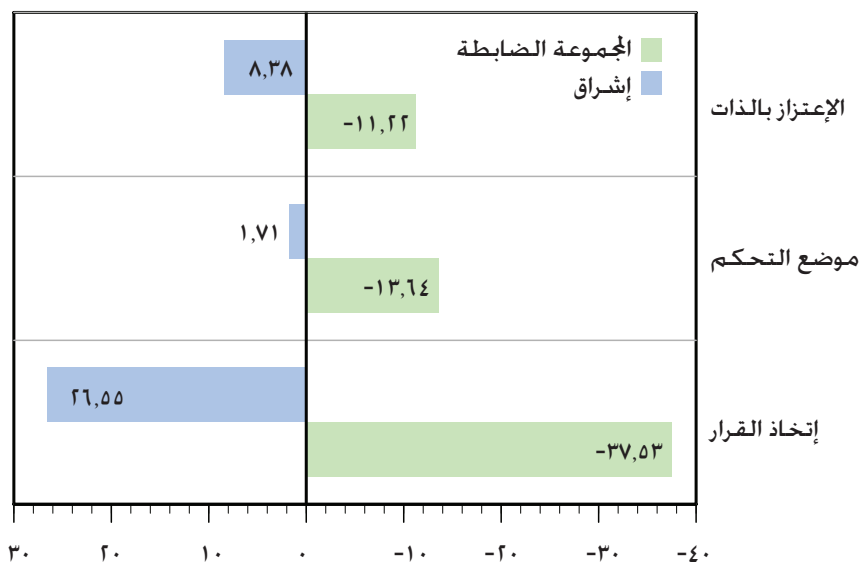

النسبة المئوية

\section{شكل (r) أسـاب قابلية مطابقة النتائع في إشـراق: الإجزاهـات نحو الزواج و تربية الأطفال}
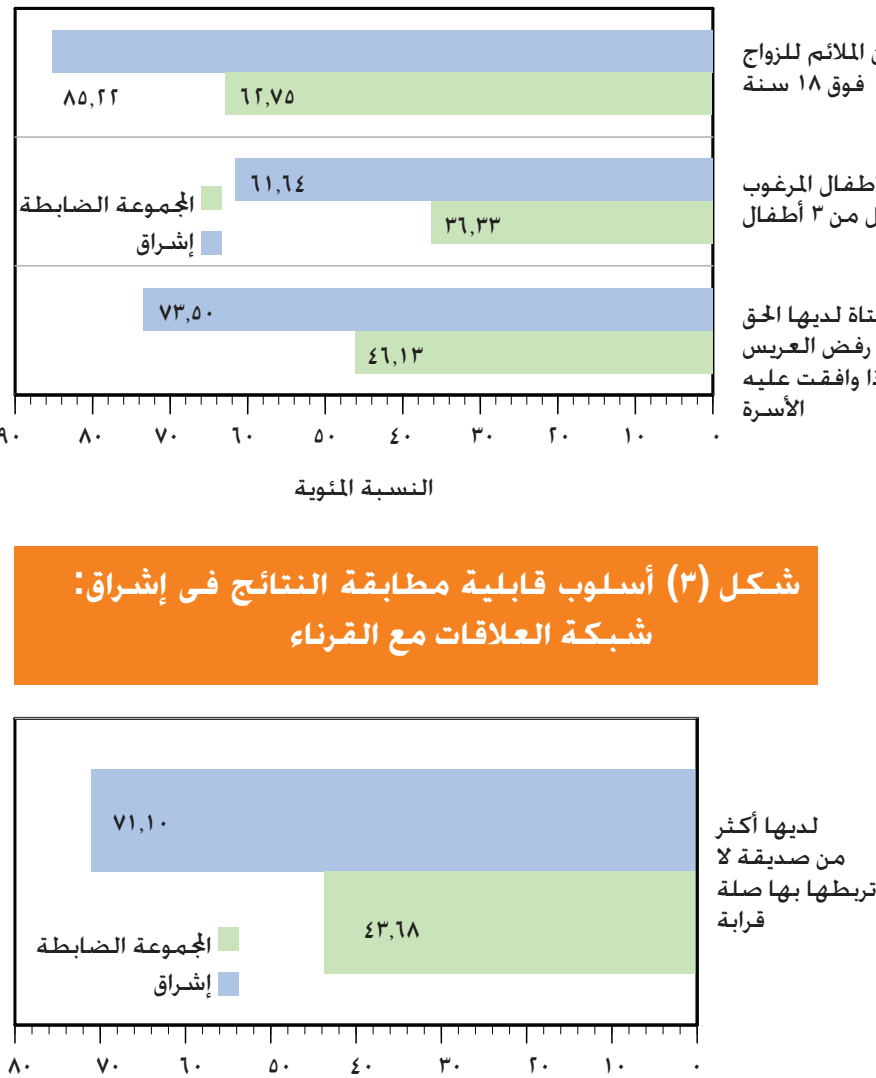

النسبة المئوية

والأدوار المنوطة بكلا الجنسين. وفيما يتعلق بالصحـة الإبجابية،

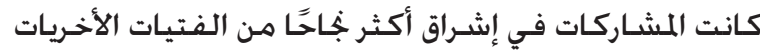

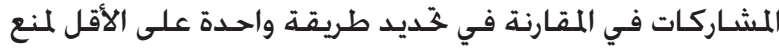

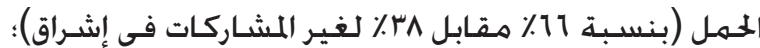

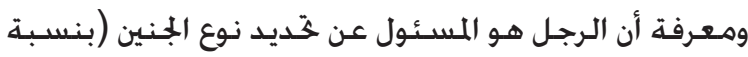

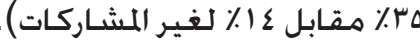


ح في البداية كانت الناس بتقول بأنه برنامهج

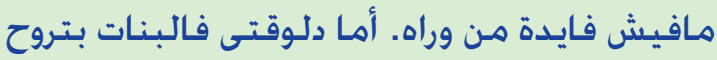

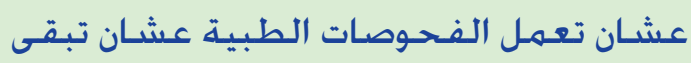
عارفة حالتها الصحية..... و بقوا يروحسوا أماكن

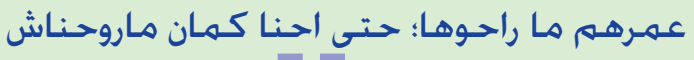
الأماكن ديـ قبل كده! - أحسد أولياء الأمهور في برنامج إشـراق

وقد أصبح مركز الشـباب مكانًا عامًا يمكن للفتيات الالتقاء

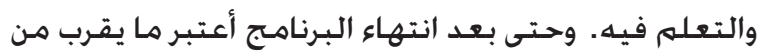

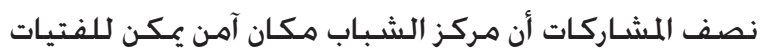

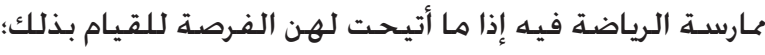

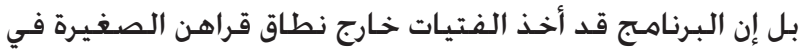
رحلات إلى الأقصر وقنا وسـوهـاج والفيوم والقاهرة.

وبالإضافة إلى ذلك، فإن البرنامج قد منحهـن الفرصة أيضًا

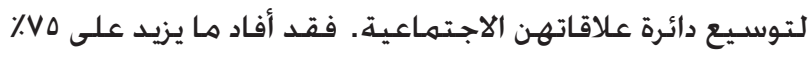

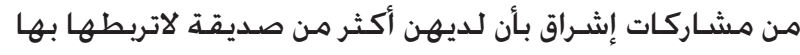

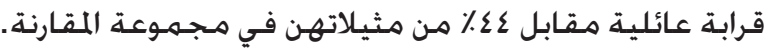

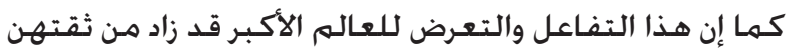
بأنفسهـن وشعـورهن بالتمكين.

\section{على المسـتوى الجمتـمعي - تغييـر العـادات والتقاليد}

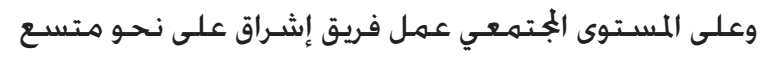

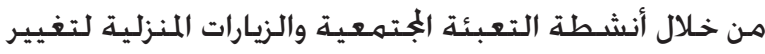

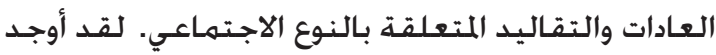

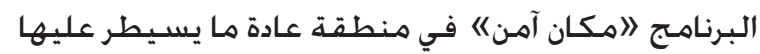
الذكور، حيث يمكن للفتيات المراهقات المتسـربات من المن التعليه

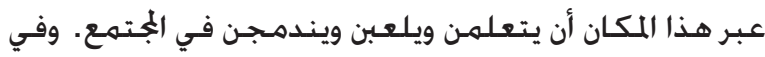

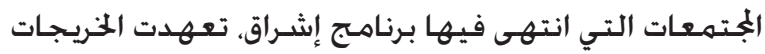
بالحفاظ على مركز الشباب كمكان آمن للالتقاء بأقرانهن.

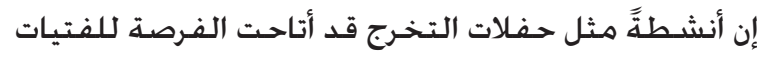

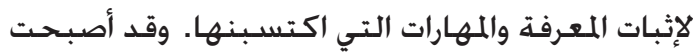

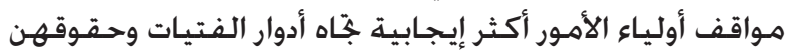
وطاقاتهن: فلقد أصبح أولياء الأمور والججتمع أكثر ارتياحًا

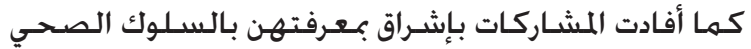

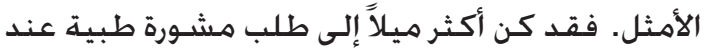

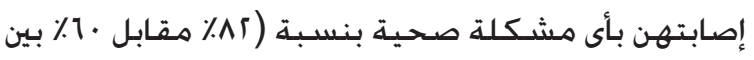

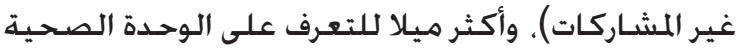

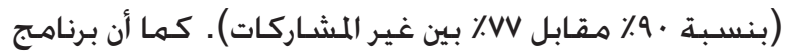

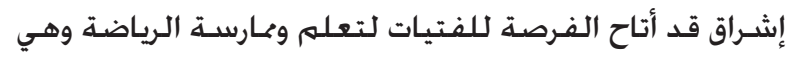

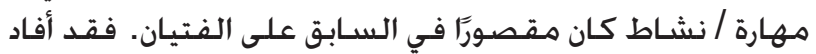

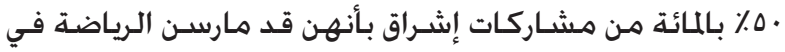

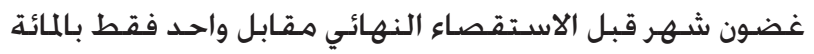
من الفتيات في الجمهوعة المقارنة.

كمـا أظهرت نتائج مرحلة التوسـع أن مشـاركات إشـراق يتمتعن

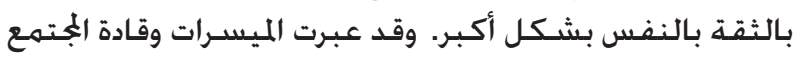

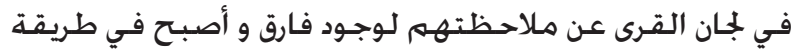

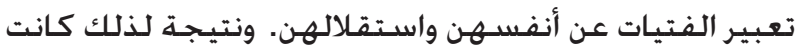

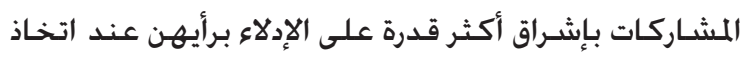

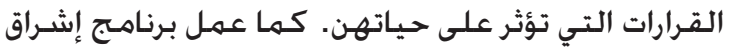

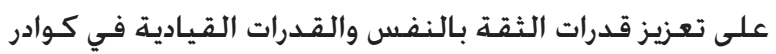

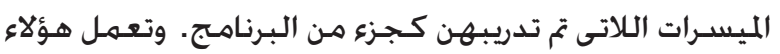
الميسـرات حاليًا قدوة للفتيات وأولياء أمورهن.

\section{ح في الأول أخـويا ماكنش موافق إنى أحضر}

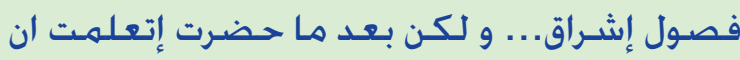

البنت لها الحق في التعبير عن رأيها ومـن وقتهـا

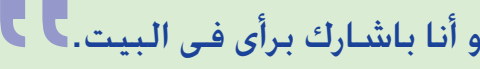
- إحـدى فتيات إشـراق، الفيوم

\section{حـرية التنقـل وتكـوين علاقات إجتـعاعية واللوصول}

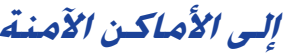

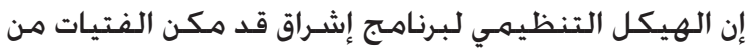

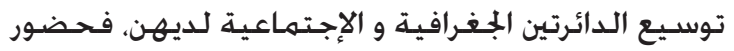

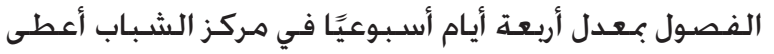

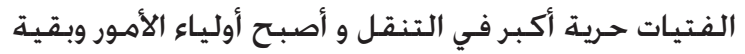

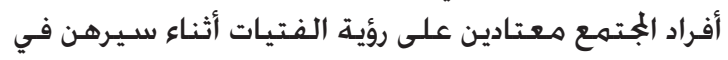

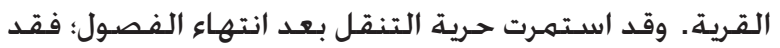

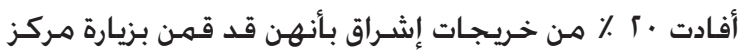

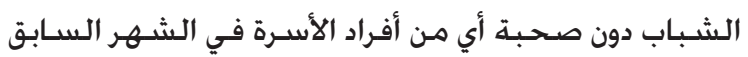

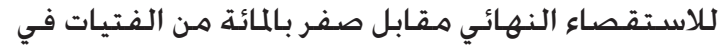

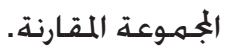


إقناع الآباء الأكثر إحجامًا بالسـماح لبناتهم بإعادة الإلتحاق

بالالتعليه الرسمي.

وفي انعكاس للإنجازات الإيجابية لبرنامسج إشـراق، ظل الإقبال

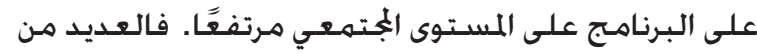

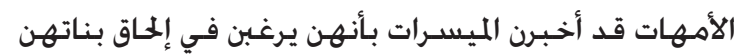

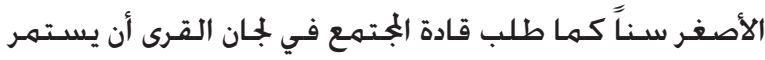

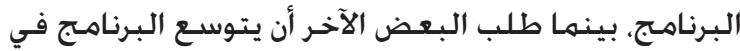

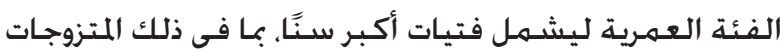

\section{المستستوى المؤسسسـي - نحـو الاسـتدامة والمأسـسـة}

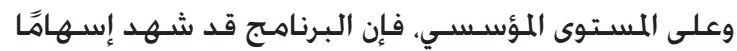

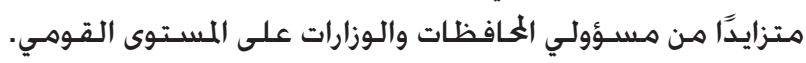

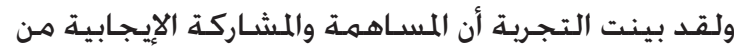

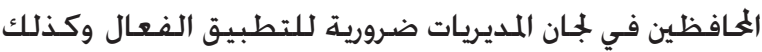

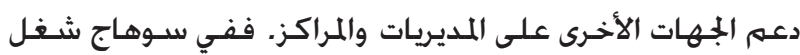

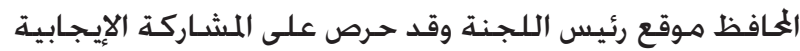

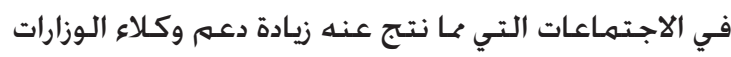
لأنشطة البرنامج.

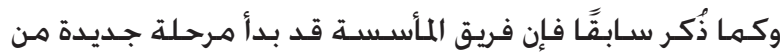

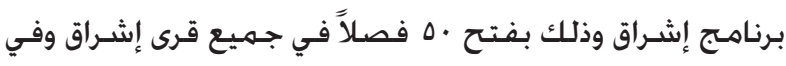

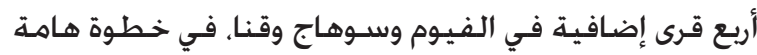

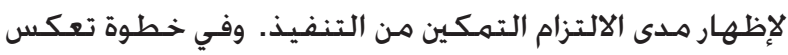

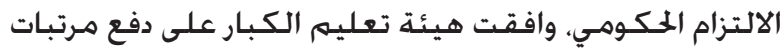
الميسـرات لهذه الفصول لمدة تسعة أشهـر.

وفي مسعى للمحافظة على مراكز الشباب كأماكن آمنة

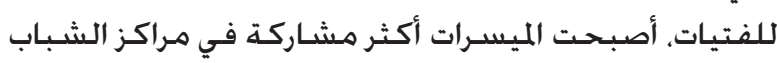

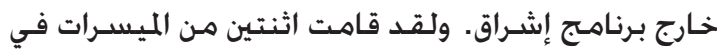

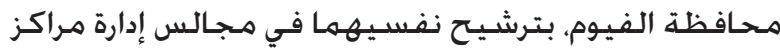

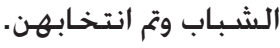

? إن خـريجـات برناهـج إشـراق اللى إلتحقـوا

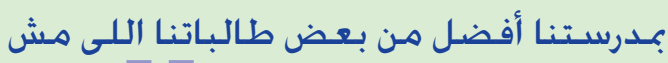
بيعرفوا حتى يكتبوا أسـمائهم. - مدير مدرسـة إعدادية بقنا

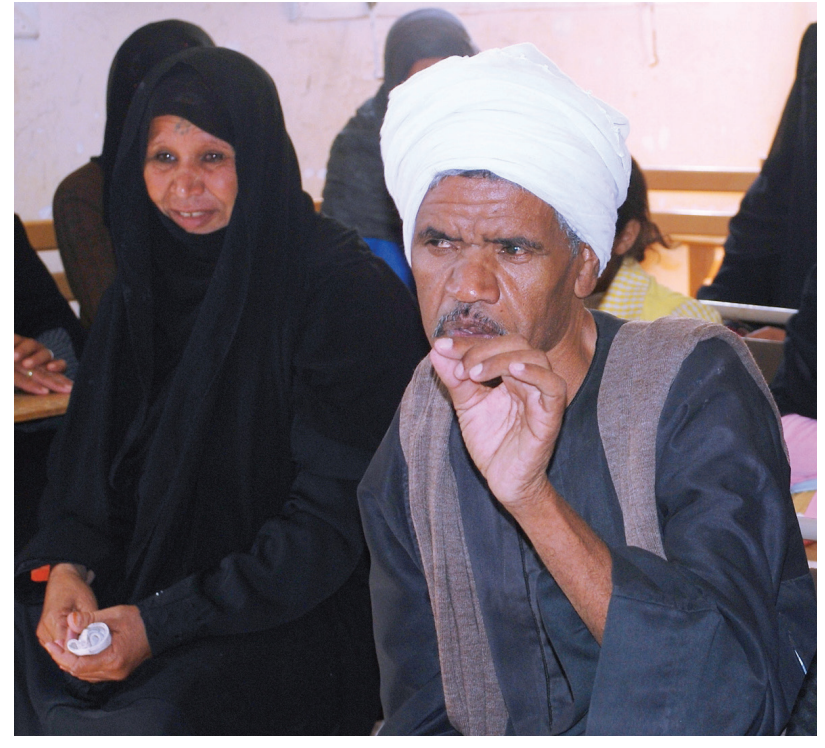

لكون مركز الشباب مكان لتجهمع فتيات إشـراق. كمها أظهر

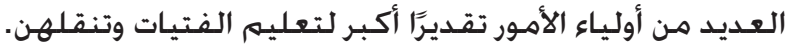

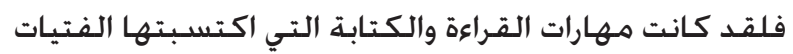

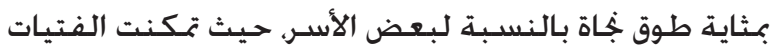

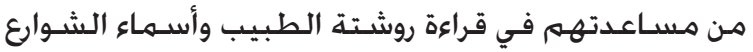

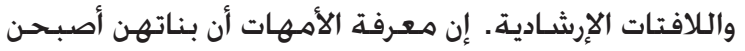

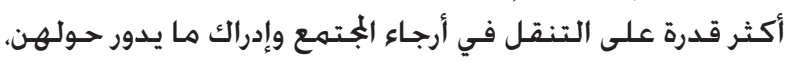

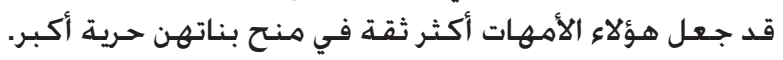

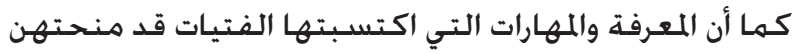

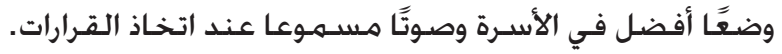

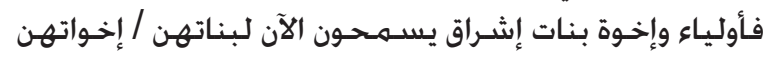

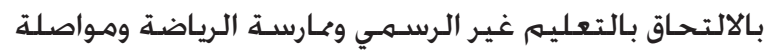

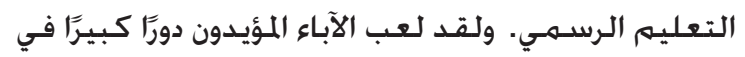

$$
\text { ? بنتى كانت أمية لا تقرأ ولا تكتب وهي }
$$

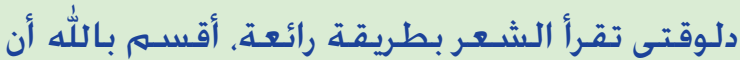
أساعدها حتى تكمعل تعليمها. - أحسد الآباء في حــل تعل تخـرج بسـوهاج

? 2

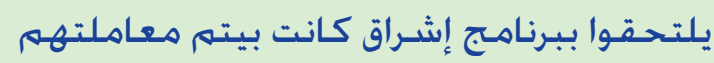

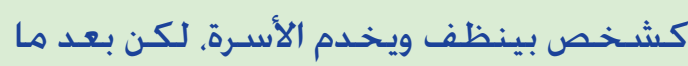
إلتحقـوا بالبرنامج بقى رأي البنت مهـم وزاد اهتمام والديها بها. ل - إحـدى الميسـرات بقنـا 
وأحيانا ما يواجهن كذلك بيئة غير مرحبة من الطلاب الآخرين

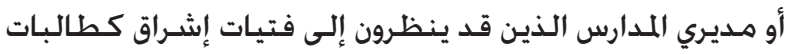

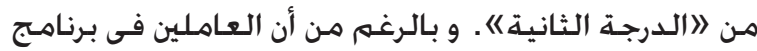

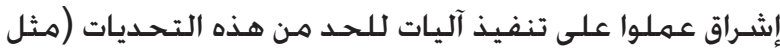

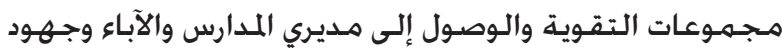

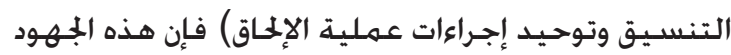

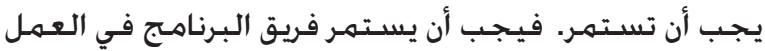

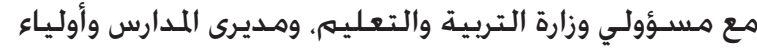

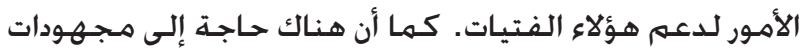

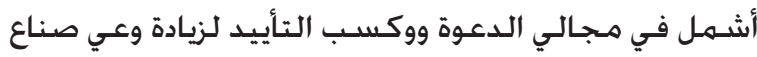

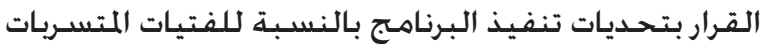

من التعليم واجتذاب دعمهم في معالجة هذه التحديات.

وإضافة إلى مـواصلة التوسع في البرنامجه، الأمـر الذي لا يزال

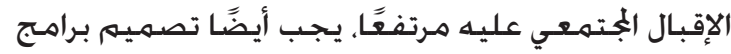

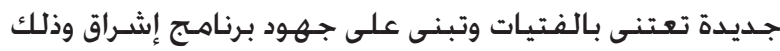

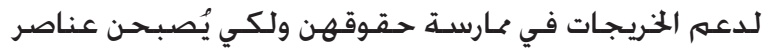

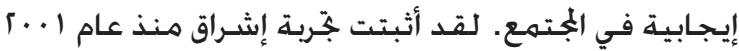

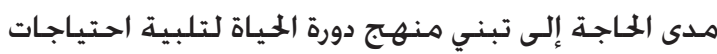

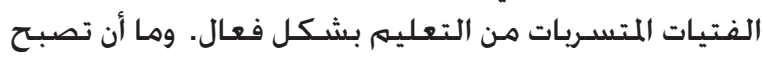

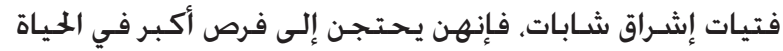

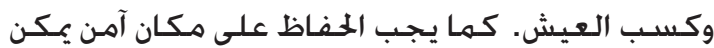

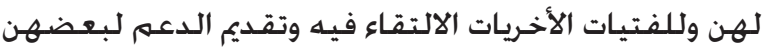

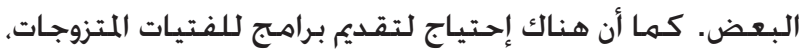
وهي فئة تعاني من الإهمال، و العديد من المشـكلات.

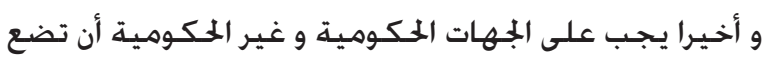

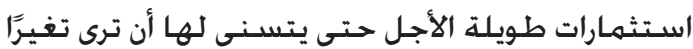

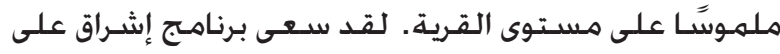

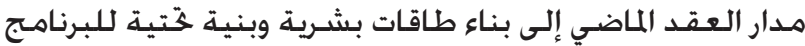

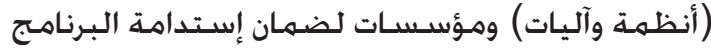

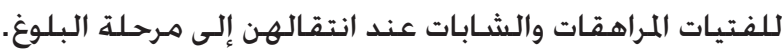

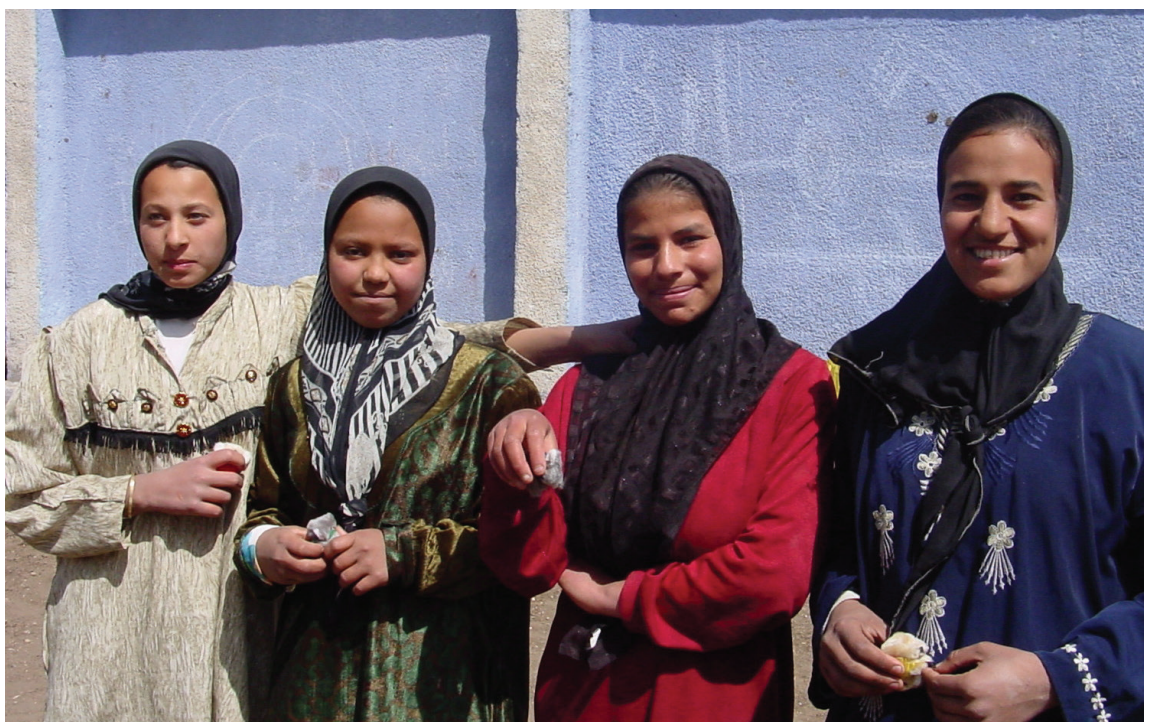

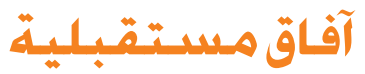

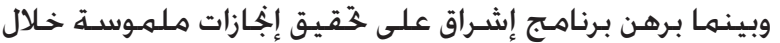

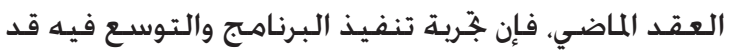

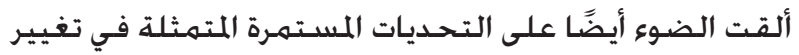

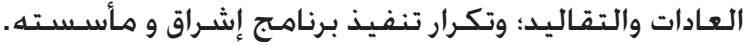

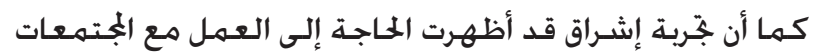

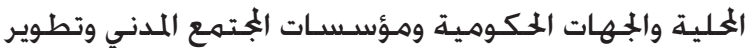

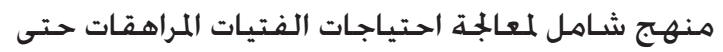

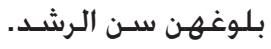

ولقد كان الحفاظ على مكان آمن دائم للفتيات في مراكز

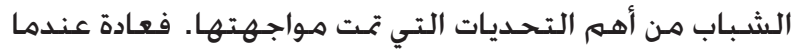

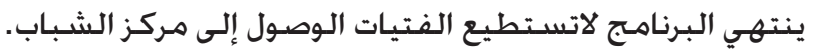

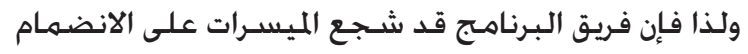

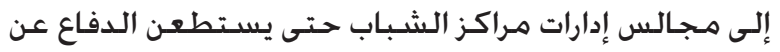

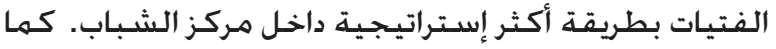

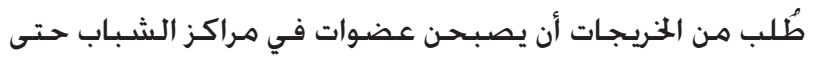

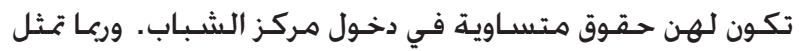

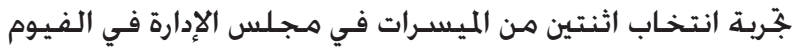

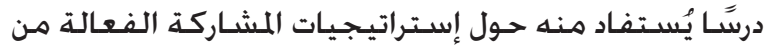
قبل الفتيات في مراكز الشباب في مرحلة ما بعد إشـراق إنسات

ولضمان إلتحاق فتيات إشـراق بالتعليم الرسـمى والنجاح فيه،

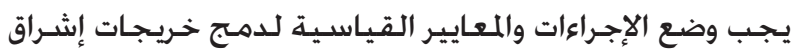

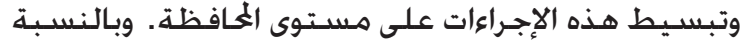

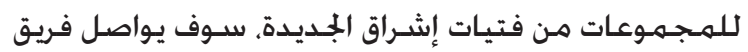

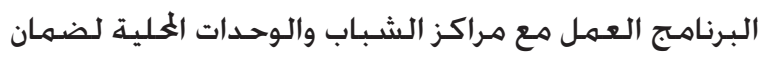

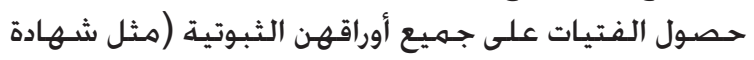

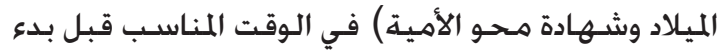

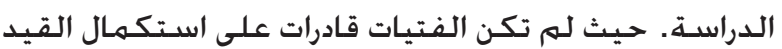

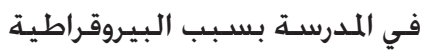

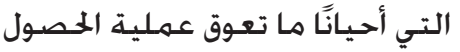
على الوثائق الرسـمية. ومن العوامل العل

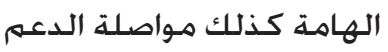
لخريجات إشـراق لاسيما أثناء السـنة

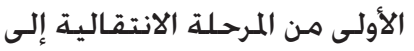
التعليهم الرسـمى. وقد تتسـرب الانتعالية إلى

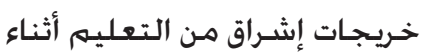
السـنة الأولى الأعدادية نتيجـة التهن لانعدام الدعم الدراسى والمالي

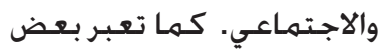
خريجات إشـراق عن صعوبة المواد الجديدة (مثل اللغة الإنجليزية والعلوم والجغرافيا) وغالباً ما لا يستطعن الائلئن والعن خممل نفقات الدروس الخصوصية. 


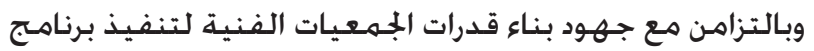

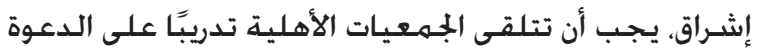

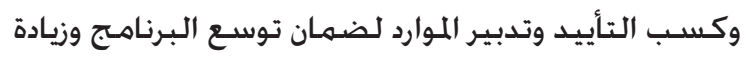

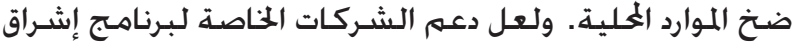

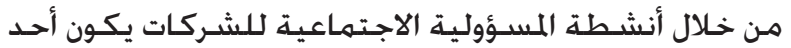

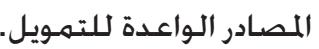

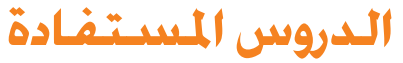

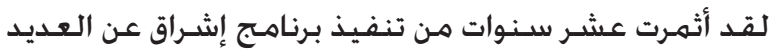

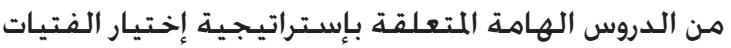

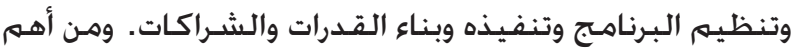

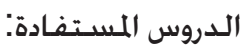

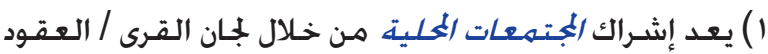

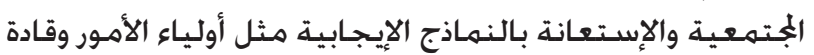

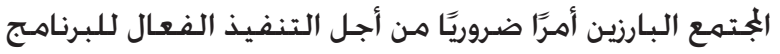

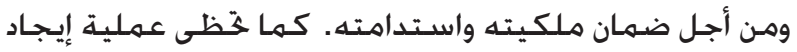

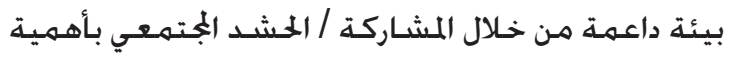

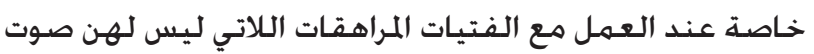

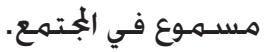

r) تعد مرونة مواعيد البرنامسج من الأمور الأسـاسية التي

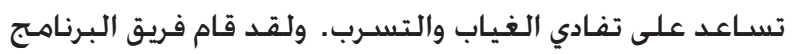

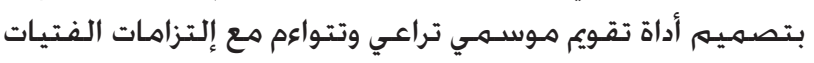

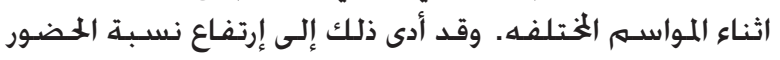

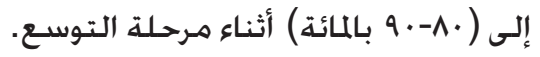

r/) لقد سـاعد التقييم الدقيق لبرنامج إشـراق على إكتساب

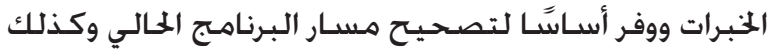

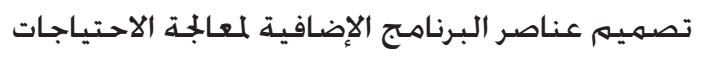

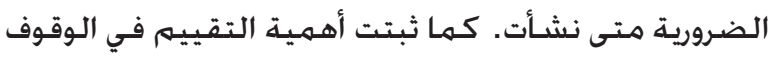
على مدى الحماجـة إلى التوسـع فـى برنامهج إشـراق.

ع) إن ثخقيق الاستـدامة يتطلب إستراتيجية متعددة الأطراف تتضمن العمل مع الججتمعات (كما هو مذكور أعلاه) والجههات

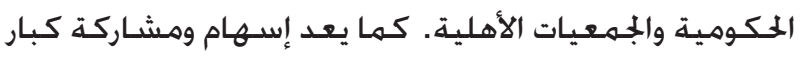

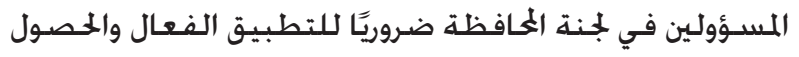

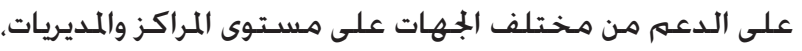

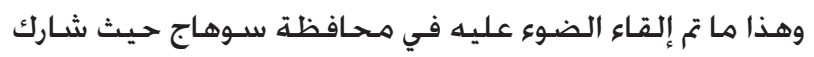
الغحافظ بصورة فعالة ومن ثم كان الدعم من الجهات الجهات الأخرى كبيرًا. 
